\title{
Recovery of Pure Pd(II) from Spent Electroplating Solutions by Solvent Extraction with Ionic Liquids from Sulfuric Acid Leaching Solution of Cemented Pd
}

\author{
Viet-NhanHoa Nguyen, Si-Jeong Song (1) and Man-Seung Lee *(i)
}

Citation: Nguyen, V.-N.; Song, S.-J.; Lee, M.-S. Recovery of Pure Pd(II) from Spent Electroplating Solutions by Solvent Extraction with Ionic Liquids from Sulfuric Acid Leaching Solution of Cemented Pd. Metals 2021, 11, 1320. https://doi.org/10.3390/ met11081320

Academic Editor: Petros E. Tsakiridis

Received: 27 July 2021

Accepted: 18 August 2021

Published: 20 August 2021

Publisher's Note: MDPI stays neutral with regard to jurisdictional claims in published maps and institutional affiliations.

Copyright: (c) 2021 by the authors. Licensee MDPI, Basel, Switzerland. This article is an open access article distributed under the terms and conditions of the Creative Commons Attribution (CC BY) license (https:// creativecommons.org/licenses/by/ $4.0 /)$.
Department of Advanced Materials Science \& Engineering, Institute of Rare Metal, Mokpo National University, Chonnam 534-729, Korea; hoahoa.tg@gmail.com (V.-N.N.); 6140r@naver.com (S.-J.S.)

* Correspondence: mslee@mokpo.ac.kr; Tel.: +82-61-450-2492

Abstract: Palladium (Pd) electroplating is widely practiced in the manufacture of advanced electronic devices. The $\mathrm{Pd}(\mathrm{II})$ present in spent electroplating solutions is treated by cementation with zinc $(\mathrm{Zn})$ metal powder. In order to recover pure Pd from the cemented Pd, a process that consisted of leaching followed by solvent extraction was investigated. For this purpose, solvent extraction experiments using synthesized ionic liquids (ILs) with organic and inorganic anions were performed to find separation conditions at which selective extraction of $\mathrm{Pd}(\mathrm{II})$ over $\mathrm{Zn}$ (II) from synthetic $\mathrm{H}_{2} \mathrm{SO}_{4}$ leaching solutions is possible. The concentration of sulfuric acid was varied from 0.5 to $9 \mathrm{M}$. The complete separation of Pd(II) over Zn(II) by ILs such as ALi-CY301 (N-methyl$N, N, N$-trioctylammonium bis(2,4,4-trimethylpentyl) dithiophosphinic), ALi-SCN (N-methyl- $N, N, N$ trioctylammonium thiocyanate), ALi-I ( $N$-methyl- $N, N, N$-trioctylammonium iodide) and ALi-Br (N-methyl- $N, N, N$-trioctylammonium bromide) depends on $\mathrm{H}_{2} \mathrm{SO}_{4}$ concentration, while ALi-LIX63 ( $N$-methyl- $N, N, N$-trioctylammonium 5,8-diethyl-7-hydroxydodecane-6-oxime) and ALi-LIX84 ( $N$ methyl- $N, N, N$-trioctylammonium 2-hydroxy-5-nonylacetophenone oxime) can completely separate $\mathrm{Pd}(\mathrm{II})$ irrespective of $\mathrm{H}_{2} \mathrm{SO}_{4}$ concentration. Additionally, the mixture of $\mathrm{HCl}$ and thiourea, aqua regia solution, $\mathrm{NH}_{3}$ solution and the mixture of $\mathrm{NH}_{4} \mathrm{Cl}$ and $\mathrm{NH}_{3}$ are powerful stripping agents for Pd(II) from the loaded ALi-LIX63/ALi-LIX84, ALi-CY301, ALi-Br/ALi-I and ALi-SCN, respectively. However, application of the separation conditions to the real $5 \mathrm{M}$ sulfuric acid leaching solutions of cemented Pd indicated that it was difficult to separate the two ions by extraction with ALi-LIX63 and ALi-LIX84. Use of $\mathrm{NaClO}$ as an oxidizing agent during the sulfuric acid leaching of real cemented Pd resulted in an enhancement of Zn(II) extraction by ALi-LIX63 and ALi-LIX84. Therefore, removal of chloride ions from the sulfuric acid leaching solutions is necessary to apply the separation conditions obtained from synthetic sulfuric acid leaching solutions.

Keywords: separation; extraction; stripping; synthesized ionic liquid; palladium

\section{Introduction}

Palladium electrodeposition has some advantages, such as easy control, versatile operating conditions, good throwing power and crack-free smooth and adherent coatings with high purity, and thus is employed in the manufacture of electronic devices and advanced materials [1,2]. The concentration of $\operatorname{Pd}(\mathrm{II})$ in the spent electroplating solutions depends on the electroplating conditions. In practice, there are many kinds of ions in the diverse spent electroplating solutions, and the concentration of $\mathrm{Pd}(\mathrm{II})$ in these solutions is not high. In order to recover $\mathrm{Pd}(\mathrm{II})$ in the spent electroplating solutions, cementation with zinc $(\mathrm{Zn})$ metal powder is generally practiced in order to concentrate Pd(II) [2]. In cementation, zinc metal powders with fine size are employed for the cementation kinetics. Therefore, it is necessary to recover pure palladium (Pd) metal from the cemented Pd. The surface of the cemented Pd is covered with Pd metal, while zinc metals exist in the interior of the cemented Pd. Leaching of the cemented Pd can be considered as a means to 
recover Pd from the cemented Pd. Since there is a lot of difference in the standard reduction potential between $\mathrm{Pd}(\mathrm{II})$ and $\mathrm{Zn}(\mathrm{II})$, leaching in the presence of oxidizing agents would lead to the complete dissolution of the Pd and $\mathrm{Zn}$ metal in the cemented Pd. Once Pd(II) and $\mathrm{Zn}(\mathrm{II})$ are completely dissolved, it is necessary to separate these two metal ions to recover $\mathrm{Pd}(\mathrm{II})$ with high purity.

Solvent extraction [3-6], ion exchange [7] and precipitation [8] are generally employed to separate $\mathrm{Pd}(\mathrm{II})$ over impurities from the leaching solution. Among these methods, solvent extraction is favorable for separation of $\mathrm{Pd}(\mathrm{II})$ due to the high selectivity and the purity of the obtained metal ion in the solution $[3,9,10]$. There are several commercial extractants that can selectively extract $\mathrm{Pd}(\mathrm{II})$ from hydrochloric acid solutions, such as 5,8-diethyl-7hydroxydodecane-6-oxime (LIX 63), Cyanex 301 (bis(2,4,4-trimethylpentyl)dithiophosphinic acid) [4], 2- hydroxy-5-nonylacetophenone oxime (LIX 84-IC) [6,11,12], dibutyl sulfoxide (DBSO) [13], $N, N^{\prime}$-dimethyl- $N, N^{\prime}$-dicyclohexylthiodiglycolamide (DMDCHTDGA) [14], tri-noctyl amine (Alamine 300) [15] and di-octylsulfide (DOS) [16]. However, solvent extraction of Pd(II) by these extractants has some drawbacks, as follows: The stripping of Pd(II) from the loaded Cyanex 301 is difficult [4], and the expensive price of DOS makes its application to the industrial scale difficult. $\mathrm{Pd}(\mathrm{II})$ extraction percentage by LIX 63 depends on the acidity of the solution [3,4].

Unlike commercial molecular extractants, ionic liquids (ILs) can overcome the abovementioned disadvantages. Indeed, ILs such as Cyphos IL 101, Aliquat 336 and their synthesized ILs have been employed for metal ion extraction because of their advantages in terms of kinetics as well as extraction efficiency [9,10,17-21]. Since ILs can extract metal ions through both ion exchange and ion pair formation mechanisms [20,22], they have been applied for metal extraction from various leachates. $\mathrm{Pd}(\mathrm{II})$ can form stable complexes with diverse anions, such as $\mathrm{I}^{-}, \mathrm{Br}^{-}, \mathrm{Cl}^{-}, \mathrm{SCN}^{-}$and $\mathrm{HSO}_{4}^{-}[23,24]$, which can be extracted into ILs phase. It has been reported that synthesized ILs such as ALi-Br and ALi-I (ALi represents Aliquat 336) are efficient to extract Pd(II) from chloride solutions [9]. The mixture of protic ionic liquids trioctylammoniumbis(trifluoromethanesulfonyl)amide $\left([\mathrm{TOAH}]\left[\mathrm{NTf}_{2}\right]\right)$ and trioctylammonium nitrate $\left([\mathrm{TOAH}]\left[\mathrm{NO}_{3}\right]\right)$ shows a selectivity for Pd(II) and Pt(IV) [25]. Two kinds of commercial ILs, such as Cyphos IL 101 and 104 (trihexyl(tetradecyl)phosphonium chloride and trihexyl-(tetradecyl)phosphonium bis-2,4,4trimethylpentylphosphinate) diluted by toluene, are employed for selective extraction of $\mathrm{Pd}(\mathrm{II})$ from a solution containing $\mathrm{Ni}(\mathrm{II}), \mathrm{Cu}(\mathrm{II}), \mathrm{Pb}(\mathrm{II}), \mathrm{Fe}(\mathrm{III}), \mathrm{Rh}(\mathrm{III}), \mathrm{Ru}(\mathrm{III})$ and $\mathrm{Pt}(\mathrm{IV})$ [10]. The undiluted imidazolium-based ILs with $\mathrm{Tf}_{2} \mathrm{~N}^{-}$as anions can extract $\mathrm{Pd}(\mathrm{II})$, and the extraction performance depends on the concentration of chloride ion [26]. Betainium bis-(trifluoromethanesulfonyl) imide IL exhibits higher extraction efficiency of Pd(II) than $\mathrm{Rh}(\mathrm{II})$ and $\mathrm{Ru}(\mathrm{III})$ from nitric acid solutions [27].

Extensive research has been reported on the solvent extraction and separation of $\mathrm{Pd}(\mathrm{II})$ from hydrochloric acid solutions containing platinum group metals and other base metal ions by using commercial extractants. Compared to hydrochloric acid medium, few works have been reported on the solvent extraction behavior of $\mathrm{Pd}(\mathrm{II})$ in sulfuric acid solution. Since commercial extractants and ILs have their characteristic advantages and disadvantages in their extraction performance, the extraction and separation behavior of Pd(II) by both commercial extractants and ILs is necessary for developing an optimum process for the recovery of $\operatorname{Pd}(\mathrm{II})$. Therefore, the objective of this study was to find appropriate IL extractants and then to develop a suitable separation process for the recovery of $\mathrm{Pd}(\mathrm{II})$ in the sulfuric acid leachate of cemented Pd from spent electroplating solutions. For this purpose, synthetic sulfuric acid leaching solutions containing Pd(II) and $\mathrm{Zn}(\mathrm{II})$ were employed in the experiments. Two kinds of ILs with organic (ALi-D2, ALi-PC, ALi-CY301, ALi-CY272, ALi-LIX63, ALi-LIX84) and inorganic species as anions (ALi-I, ALi-Br, ALi-SCN) were employed to separate Pd(II) and $\mathrm{Zn}(\mathrm{II})$ from the synthetic sulfuric acid leaching solutions. These ILs were prepared by reacting Aliquat $336(\mathrm{~N}$ Methyl- $N, N, N$-trioctylammonium chloride) with anionic group of organophosphorus acids, such as D2EHPA (di(2-ethylhexyl)phosphoric acid), PC 88A (2-ethylhexyl hydrogen- 
2-ethylhexylphosphonate), Cyanex 301, Cyanex 272 (bis(2,4,4-triethylpentyl)phosphinic acid), LIX 63, LIX 84, as well as the anions of inorganic salts (KI, KBr, KSCN) (see Scheme 1). The extraction and separation behavior of the two metal ions was investigated by varying the acidity of the synthetic sulfuric acid solutions. From the obtained results, the advantages and disadvantages of the separation of Pd(II) by these synthesized ILs were discussed. The stripping behavior of each loaded organic phase was also explored. Based on the obtained results, some suitable ILs were proposed for the selective extraction of $\mathrm{Pd}$ (II) from the leaching solution of cemented Pd.

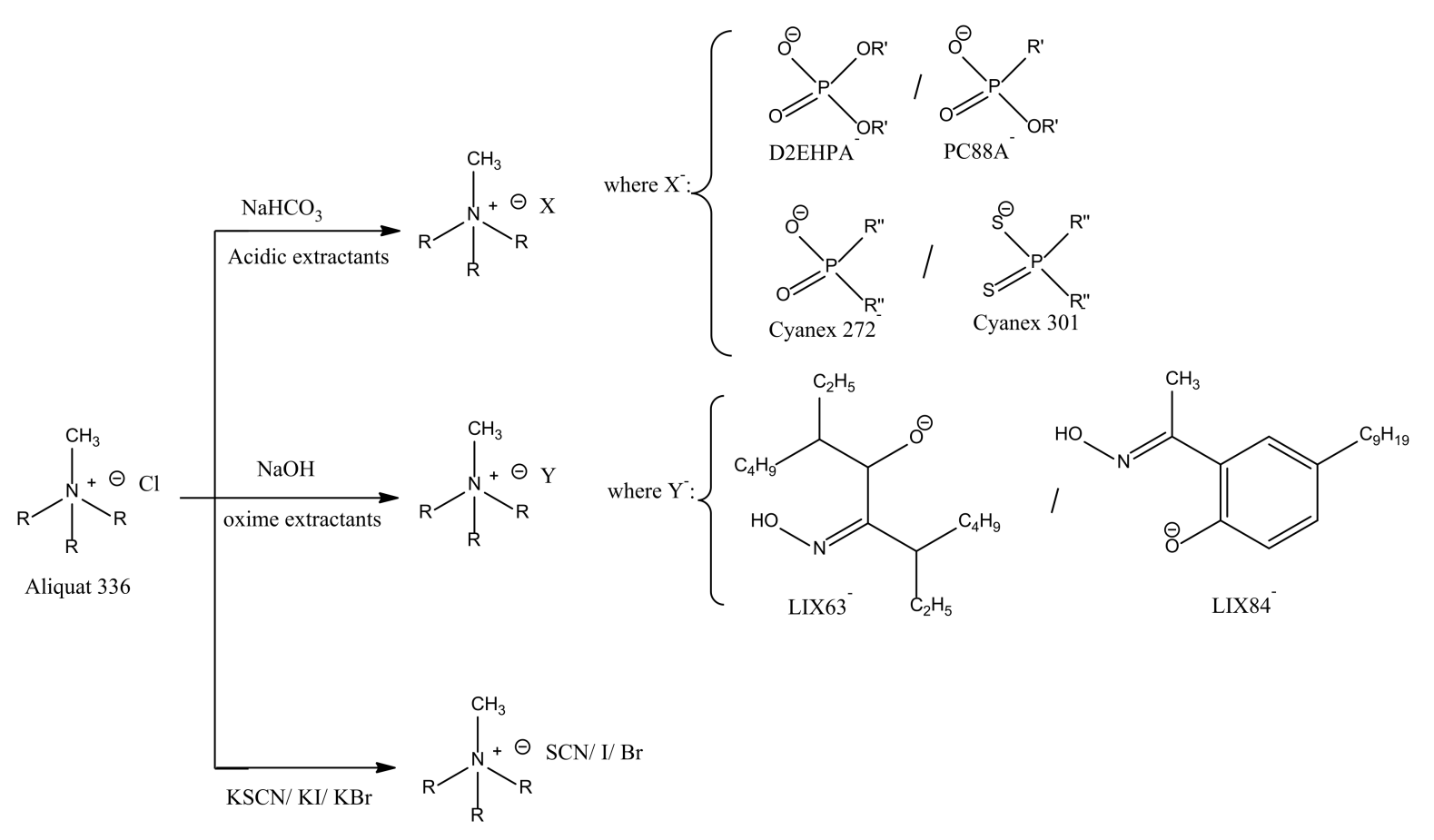

Scheme 1. The synthesis of ILs with organic and inorganic anions.

\section{Experimental}

\subsection{Reagents and Chemicals}

Aliquat 336 (93\%) and LIX 84 (99\%) were supplied by BASF Co., Ludwigshafen, Germany, PC 88A (95\%), Cyanex $272(85 \%)$ and Cyanex $301(70 \%)$ were provided by Cytec Inc., Saddle Brook, NJ, USA, and D2EHPA (95\%) and LIX 63 (70\%) were products of Daihachi Chem., Osaka, Japan, and IS Chem. Co., Seoul, Korea, respectively. All extractants were used without further purification. Organic phases were prepared by diluting the extractants with kerosene (Daejung Co., Shiheung, Korea, >90\%). Decanol (Daejung Co., Shiheung, Korea, $>98 \%)$ was added into organic solution $(10 \% v / v)$ as a modifier to avoid the formation of a third phase.

The synthetic leaching solutions containing $100 \mathrm{mg} / \mathrm{L}$ of $\mathrm{Pd}(\mathrm{II})$ and $500 \mathrm{mg} / \mathrm{L}$ of $\mathrm{Zn}$ (II) were prepared by dissolving the corresponding amount of metal sulfates, such as $\mathrm{PdSO}_{4}$ (Sigma-Aldrich Co., St. Louis, MO, USA, 99.9\%) and $\mathrm{ZnSO}_{4}$ (Duksan Co., Kyungkido, Korea, $99 \%$ ), in $\mathrm{H}_{2} \mathrm{SO}_{4}$ solution. The acidity of the synthetic solution was controlled from 0.5 to $9 \mathrm{M}$ by adding $\mathrm{H}_{2} \mathrm{SO}_{4}$ (Daejung Co., Shiheung, Korea, 95\%) solution. $\mathrm{HCl}$ (Daejung Co., Shiheung, Korea, 35\%), $\mathrm{HNO}_{3}$ (Daejung Co., Shiheung, Korea, 60\%) and $\mathrm{H}_{2} \mathrm{SO}_{4}$ solutions were diluted by distilled water to desired concentrations for stripping experiments. Thiourea $\left(\left(\mathrm{NH}_{2}\right)_{2} \mathrm{CS}\right.$, Daejung Co., Shiheung, Korea, $\left.>96 \%\right)$ and $\mathrm{NH}_{3}$ (Junsei Co., Tokyo, Japan, $28 \%$ ) solutions were used as stripping agents, and all the employed chemicals were of analytical grade. 


\subsection{Synthesis of Ionic Liquids}

Ionic liquids such as ALi-D2, ALi-PC, $\mathrm{ALi}-\mathrm{CY}$ and $\mathrm{ALi}-\mathrm{CY} 301\left(\mathrm{R}_{3} \mathrm{CH}_{3} \mathrm{~N} \cdot \mathrm{A}\right)$ were prepared according to the method reported in the literature [28]: an equimolar concentration of Aliquat 336 and acidic extractants in kerosene were mixed in a beaker, and then $0.5 \mathrm{M} \mathrm{NaHCO}_{3}$ solution was added. The mixtures were stirred to expel $\mathrm{CO}_{2}$ gas and to promote the formation of bi-functional ILs. ALi-SCN $\left(\mathrm{R}_{3} \mathrm{CH}_{3} \mathrm{~N} \cdot \mathrm{SCN}\right)$ was synthesized by contacting Aliquat 336 and the aqueous solution of $1.6 \mathrm{M} \mathrm{KSCN}$ several times for the complete replacement of chloride with thiocyanate [19,22]. ALi-LIX63/LIX 84 were obtained by mixing an equimolar concentration of Aliquat 336 and LIX 63/LIX 84 in kerosene, and then $2 \mathrm{M} \mathrm{NaOH}$ was added. These organic mixtures were contacted four times with $\mathrm{NaOH}$ solution for the complete formation of ILs. These synthesized ILs were washed many times with distilled water and then filtered.

In the case of $\mathrm{ALi}-\mathrm{SCN}$, chloride precipitation using $\mathrm{AgNO}_{3}$ was performed to verify the transfer of the chloride ions from the organic phase to the aqueous phase. ALi-I and $\mathrm{ALi}-\mathrm{Br}$ were prepared according to the literature [9], in which the complete replacement of chloride with iodide or bromide was achieved by reacting Aliquat 336 and $3 \mathrm{M} \mathrm{KI}$ or $\mathrm{KBr}$ solutions. After contacting of the organic phase three times with the fresh $\mathrm{KBr}$ or $\mathrm{KI}$ solution at the same experimental conditions, the synthesized ILs were washed many times with water to remove chloride and impurities. The structure and synthesis of these ILs are exhibited in Scheme 1.

In order to investigate the formation of ILs, the FT-IR spectra (FT-IR-Vertex $80 \mathrm{~V}$, Bruker, Leipzig, Germany) of individual extractants and synthesized ILs were analyzed. The ILs were synthesized when the interaction occurred in functional groups of a single extractant such as LIX 63/LIX 84/Cyanex 301 and Aliquat 336, leading to some changes in the characteristic groups. Therefore, the changes in the characteristic bands of the acidic/oxime extractants before and after being mixed with Aliquat 336 were recorded and are shown in Figure 1 and Table 1 . The region of 3500-500 $\mathrm{cm}^{-1}$ spectra was analyzed in more detail, where changes were observed. The data show that there was a significant change in the characteristic bands of the synthesized ILs, denoting that LIX 63/LIX 84 and Cyanex 301 reacted with Aliquat 336 to form ILs. The evidence is the occurrence of a significant change in the range of $\mathrm{P}-\mathrm{S}, \mathrm{P}=\mathrm{S}, \mathrm{S}-\mathrm{H}$ (thiophosphinic group) and $\mathrm{C}-\mathrm{O}, \mathrm{C}-\mathrm{OH}$, $\mathrm{C}=\mathrm{N}$ (oxime group). It is easier to observe the transformation of the $\mathrm{C}-\mathrm{OH}$ group of LIX 84 than that of LIX 63 because this functional group $(-\mathrm{OH})$ directly links to the benzene cycle, which makes this hydroxyl group more active and easier to participate in chemical reaction. Moreover, the drastic decrease in the intensities or even disappearance of the $\left(\mathrm{CH}_{3}\right)^{+} \mathrm{N}$ peak at $1463 \mathrm{~cm}^{-1}$ of Aliquat 336 was observed after synthesis of ILs, indicating the occurrence of strong and effective interaction at that position. This also agrees well with the reported spectra data [29]. From the evidence of significant changes on characteristic bands, it can be verified that the targeted ILs were successfully synthesized from the reactants.

Table 1. Frequencies of characteristic vibrational bands of single extractants and corresponding synthesized IL.

\begin{tabular}{|c|c|c|c|c|c|c|c|c|c|}
\hline Extractant & $\begin{array}{c}\mathrm{C}-\mathrm{O} \\
\left(\mathrm{cm}^{-1}\right)\end{array}$ & $\begin{array}{l}\mathrm{C}-\mathrm{O}-\mathrm{H} \\
\left(\mathrm{cm}^{-1}\right)\end{array}$ & $\begin{array}{c}\mathrm{C}=\mathrm{N} \\
\left(\mathrm{cm}^{-1}\right)\end{array}$ & $\begin{array}{l}\mathrm{N}-\mathrm{O}-\mathrm{H} \\
\left(\mathrm{cm}^{-1}\right)\end{array}$ & $\begin{array}{c}\mathrm{P}-\mathrm{S} \\
\left(\mathrm{cm}^{-1}\right)\end{array}$ & $\begin{array}{c}\mathrm{P}=\mathrm{S} \\
\left(\mathrm{cm}^{-1}\right)\end{array}$ & $\begin{array}{c}\mathrm{S}-\mathrm{H} \\
\left(\mathrm{cm}^{-1}\right)\end{array}$ & $\begin{array}{c}\mathrm{C}-\mathrm{H} \\
\left(\mathrm{cm}^{-1}\right)\end{array}$ & $\begin{array}{c}\left(\mathrm{CH}_{3}\right)^{+} \mathrm{N} \\
\left(\mathrm{cm}^{-1}\right)\end{array}$ \\
\hline Aliquat 336 & - & - & & - & - & - & - & 1378 & 1463.6 \\
\hline LIX 84 & 1025.6 & 1375 & 1620 & 3370 & - & - & - & - & - \\
\hline LIX 63 & 998 & 1382 & 1706 & 3370 & - & - & - & - & - \\
\hline Cyanex 301 & - & - & - & - & 804 & 608 & $\approx 2500$ & 1365 & - \\
\hline ALi-LIX84 & 1096 & 1409 & 1620 & 3370 & - & - & - & - & - \\
\hline ALi-LIX63 & 1014 & 1377 & 1668 & 3370 & - & - & - & - & 1463.6 \\
\hline ALi-CY301 & - & - & - & - & 814 & 613.9 & - & 1365 & 1479.7 \\
\hline
\end{tabular}




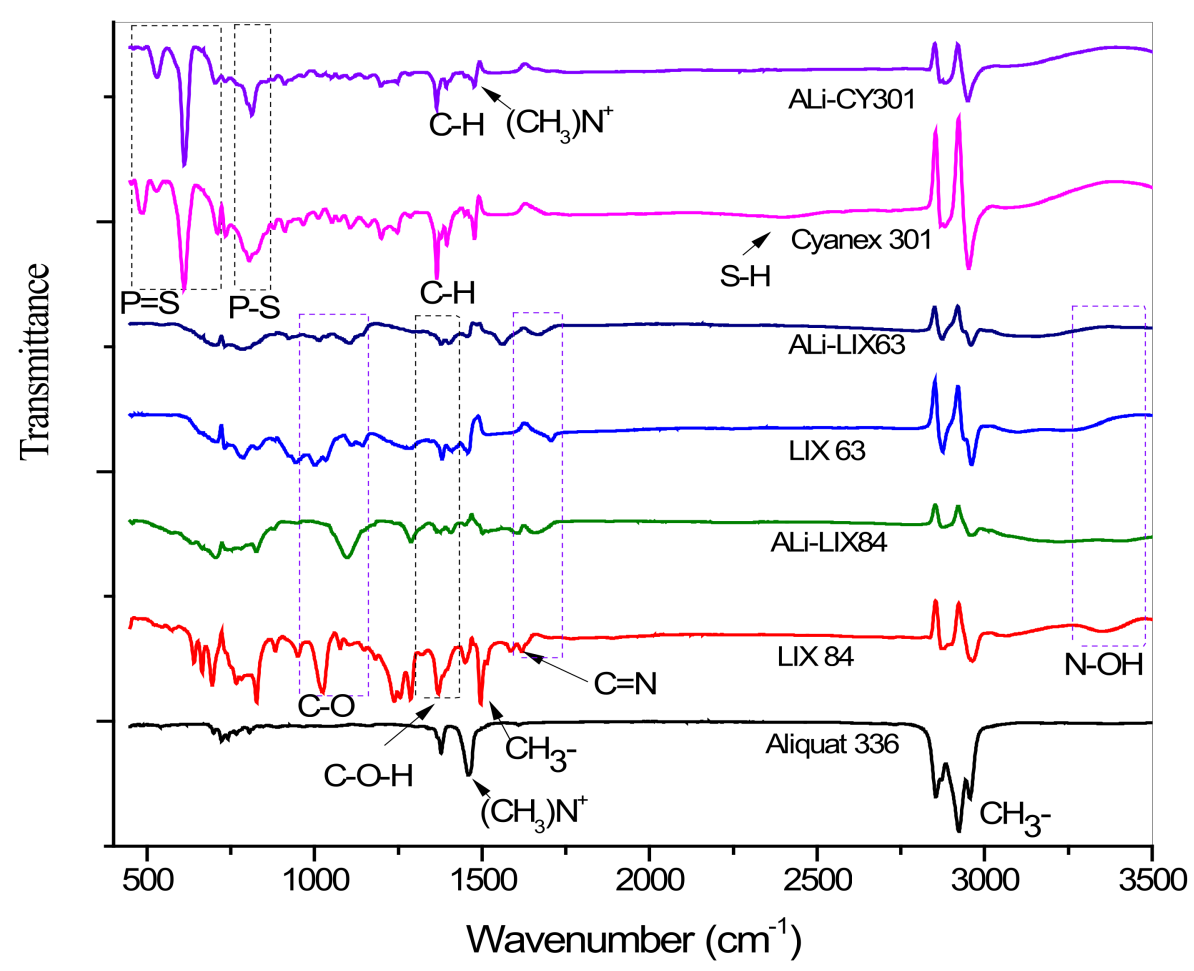

Figure 1. Comparison on FT - IR spectra of single extractants and the synthesized ILs, such as ALi-LIX63, ALi-LIX84 and ALi-CY301.

\subsection{Experimental Procedure and Analytical Methods}

The solvent extraction experiments were performed by mixing equal volume of the aqueous and organic phase $(10 \mathrm{~mL}$ each) in a screwed cap bottle. The mixtures were stirred for 30 min using a Burrell wrist action shaker (model 75, Pittsburgh, PA 15205, USA) at ambient temperature $\left(22 \pm 1{ }^{\circ} \mathrm{C}\right)$. After shaking, the two phases were disengaged by keeping them in a glass separatory funnel for $30 \mathrm{~min}$. The extraction percentage (\%E) and stripping percentage $(\% \mathrm{~S})$ of metals are defined as:

$$
\begin{aligned}
& \% \mathrm{E}=\frac{\mathrm{m}_{\mathrm{M}}}{\mathrm{m}} \times 100, \\
& \% \mathrm{~S}=\frac{\mathrm{m}_{\mathrm{M}}^{*}}{\mathrm{~m}_{\mathrm{M}}} \times 100,
\end{aligned}
$$

where $m$ and $m_{M}$ are the mass of a metal in the aqueous phase before extraction and in the loaded organic phase respectively, while $\mathrm{m}^{*} \mathrm{M}$ is the mass of metal in the aqueous phase after stripping from the loaded organic phase.

The mass of metals was calculated according to volume and the concentration of metal ions in the aqueous phase before and after extraction/stripping. The concentration of metal ions was determined by inductively coupled plasma-optical emission spectrometry (ICP-OES, Spectro Arcos). The experiments were performed in triplicate and the errors associated with the extraction and stripping percentages were within $\pm 5 \%$.

\section{Results and Discussion}

\subsection{Effect of $\mathrm{H}_{2} \mathrm{SO}_{4}$ Concentration on the Separation of Pd(II) over $\mathrm{Zn}(\mathrm{II})$}

In our previous work, the concentration of both $\mathrm{Pd}(\mathrm{II})$ and $\mathrm{Zn}(\mathrm{II})$ in the sulfuric acid leaching solution was the same $(1000 \mathrm{mg} / \mathrm{L})$ [2]. However, the concentration of these two ions in the leaching solution depends on the size, composition and pulp density of the cemented $\mathrm{Pd}$ in the leaching. Considering that $\mathrm{Pd}$ metal is much more expensive than $\mathrm{Zn}$ metal, excess Zn metal would be present in the cemented Pd. Therefore, the 
concentration of $\mathrm{Zn}(\mathrm{II})$ was controlled to five times that of $\mathrm{Pd}(\mathrm{II})$ in this work. Namely, the concentrations of $\mathrm{Pd}(\mathrm{II})$ and $\mathrm{Zn}$ (II) in the synthetic leaching solution were fixed at 100 and $500 \mathrm{mg} / \mathrm{L}$, respectively. Moreover, the excess $\mathrm{Zn}$ (II) was used in these experiments in order to investigate the effect of $\mathrm{Zn}$ (II) on selective separation of $\mathrm{Pd}(\mathrm{II})$. The $\mathrm{H}_{2} \mathrm{SO}_{4}$ concentration was varied from 0.5 to $9 \mathrm{M}$ in this study. Once the suitable range of $\mathrm{H}_{2} \mathrm{SO}_{4}$ concentration was discovered, the selective extraction of $\mathrm{Pd}(\mathrm{II})$ from such real leaching solution of cemented Pd would be performed.

Dissociation of sulfuric acid occurs in two steps, and the second dissociation of hydrogen sulfate depends on the concentration of sulfuric acid. As the concentration of sulfuric acid increases, the existence of hydrogen ions depresses the second dissociation of hydrogen sulfate. Therefore, hydrogen sulfate is the dominant species of sulfuric acid in concentrated sulfuric acid solution. The complex formation constants of $\mathrm{Pd}(\mathrm{II})$ with hydrogen sulfate and sulfate ions are represented in Equations (3) and (4) [24]:

$$
\begin{gathered}
{\left[\mathrm{Pd}\left(\mathrm{H}_{2} \mathrm{O}\right)_{4}\right]^{2+}+\mathrm{HSO}_{4}{ }^{-}=\left[\mathrm{Pd}\left(\mathrm{H}_{2} \mathrm{O}\right)_{3} \mathrm{HSO}_{4}\right]^{+}+\mathrm{H}_{2} \mathrm{O} ; \log _{\mathrm{K} 1}=-0.15} \\
{\left[\mathrm{Pd}\left(\mathrm{H}_{2} \mathrm{O}\right)_{4}\right]^{2+}+\mathrm{SO}_{4}{ }^{2-}=\left[\mathrm{Pd}\left(\mathrm{H}_{2} \mathrm{O}\right)_{3} \mathrm{SO}_{4}\right]+\mathrm{H}_{2} \mathrm{O} ; \log _{\mathrm{K} 2}=1.28}
\end{gathered}
$$

Compared to the complex formation constants of $\mathrm{Pd}(\mathrm{II})$ with sulfate/hydrogen sulfate ions, the complex formation constants with $\mathrm{SCN}^{-}, \mathrm{I}^{-}$and $\mathrm{Br}^{-}$are large, as represented in Table $2[23,24,30-34]$, and these complexes can be extracted by the ammonium cation of the corresponding ILs owing to their affinity. In addition, $\mathrm{Pd}(\mathrm{II})$ has a stronger tendency to form stable complexes with these inorganic anions than that of $\mathrm{Zn}(\mathrm{II})$, thus the selective separation could be obtained on the basis of the difference in formation of extracted complexes. Preliminary experimental data indicated that $\mathrm{Pd}(\mathrm{II})$ was well-extracted by both ILs with organic anions (ALi-CY 301, ALi-LIX63, ALi-LIX84) and ILs with inorganic anions (ALi-SCN, ALi-I, ALi-Br). In these experiments, the concentration of ILs was fixed at $0.1 \mathrm{M}$. The volume ratio of organic to aqueous phase was unity.

\begin{tabular}{|c|c|c|c|}
\hline Reaction & $\log K$ & Reaction & $\log K$ \\
\hline $\mathrm{Pd}^{2+}+\mathrm{Cl}^{-}=\mathrm{PdCl}^{+}$ & 4.47 & $\mathrm{Pd}^{2+}+2 \mathrm{SCN}^{-}=\mathrm{Pd}(\mathrm{SCN})_{2}{ }^{\mathrm{o}}$ & 15.46 \\
\hline $\mathrm{Pd}^{2+}+2 \mathrm{Cl}^{-}=\mathrm{PdCl}_{2}{ }^{\mathrm{O}}$ & 7.74 & $\mathrm{Pd}^{2+}+3 \mathrm{SCN}^{-}=\mathrm{Pd}(\mathrm{SCN})_{3}^{-}$ & 21.94 \\
\hline $\mathrm{Pd}^{2+}+3 \mathrm{Cl}^{-}=\mathrm{PdCl}_{3}^{-}$ & 10.2 & $\mathrm{Pd}^{2+}+4 \mathrm{SCN}^{-}=\mathrm{Pd}(\mathrm{SCN})_{4}^{2-}$ & 27.42 \\
\hline $\mathrm{Pd}^{2+}+4 \mathrm{Cl}^{-}=\mathrm{PdCl}_{4}^{2-}$ & 11.5 & $\mathrm{Zn}^{2+}+\mathrm{Cl}^{-}=\mathrm{ZnCl}^{+}$ & 0.43 \\
\hline $\mathrm{Pd}^{2+}+\mathrm{Br}^{-}=\mathrm{PdBr}^{+}$ & 5.17 & $\mathrm{Zn}^{2+}+2 \mathrm{Cl}^{-}=\mathrm{ZnCl}_{2}{ }^{\mathrm{o}}$ & 0.61 \\
\hline $\mathrm{Pd}^{2+}+2 \mathrm{Br}^{-}=\mathrm{PdBr}_{2}{ }^{\mathrm{O}}$ & 9.42 & $\mathrm{Zn}^{2+}+3 \mathrm{Cl}^{-}=\mathrm{ZnCl}_{3}^{-}$ & 0.5 \\
\hline $\mathrm{Pd}^{2+}+3 \mathrm{Br}^{-}=\mathrm{PdBr}_{3}^{-}$ & 12.72 & $\mathrm{Zn}^{2+}+4 \mathrm{Cl}^{-}=\mathrm{ZnCl}_{4}^{2-}$ & 0.2 \\
\hline $\mathrm{Pd}^{2+}+4 \mathrm{Br}^{-}=\mathrm{PdBr}_{4}^{2-}$ & 14.94 & $\mathrm{Zn}^{2+}+\mathrm{Br}^{-}=\mathrm{ZnBr}^{+}$ & -0.57 \\
\hline $\mathrm{Pd}^{2+}+\mathrm{I}^{-}=\mathrm{PdI}^{+}$ & 6.08 & $\mathrm{Zn}^{2+}+\mathrm{I}^{-}=\mathrm{ZnI}^{+}$ & -1.50 \\
\hline $\mathrm{Pd}^{2+}+2 \mathrm{I}^{-}=\mathrm{PdI}_{2}^{\mathrm{o}}$ & 22.00 & $\mathrm{Zn}^{2+}+\mathrm{SCN}^{-}=\mathrm{ZnNSC}^{+}$ & 0.90 \\
\hline $\mathrm{Pd}^{2+}+3 \mathrm{I}^{-}=\mathrm{PdI}_{3}^{-}$ & $\approx 25.80$ & $\mathrm{Zn}^{2+}+2 \mathrm{SCN}^{-}=\mathrm{Zn}(\mathrm{NSC})_{2}{ }^{\mathrm{O}}$ & 0.70 \\
\hline $\mathrm{Pd}^{2+}+4 \mathrm{I}^{-}=\mathrm{PdI}_{4}^{2-}$ & 28.30 & $\mathrm{Zn}^{2+}+3 \mathrm{SCN}^{-}=\mathrm{Zn}(\mathrm{NSC})_{3}-$ & 0.60 \\
\hline $\mathrm{Pd}^{2+}+\mathrm{SCN}^{-}=\mathrm{PdSCN}^{+}$ & 8.14 & $\mathrm{Zn}^{2+}+4 \mathrm{SCN}^{-}=\mathrm{Zn}(\mathrm{NSC})_{4}^{2-}$ & 0.30 \\
\hline
\end{tabular}

Table 2. The stability constants of metal complexes at $25^{\circ} \mathrm{C}$ [30-34].

Figure 2 shows that the extraction percentage of Pd(II) by ALi-CY 272, ALi-D2 and ALi-PC was lower than $25 \%$, while that of $\mathrm{Zn}$ (II) was less than $5 \%$. Compared to other ILs with organophosphorus anions, ALi-CY 301 can completely extract $\mathrm{Pd}$ (II) from $\mathrm{H}_{2} \mathrm{SO}_{4}$ in the concentration range between 0.5 and $9 \mathrm{M}$, while the extraction percentage of $\mathrm{Zn}$ (II) gradually decreased from $74.7 \%$ to $8.2 \%$ as $\mathrm{H}_{2} \mathrm{SO}_{4}$ concentration increased from 0.5 to $9 \mathrm{M}$. The higher extraction percentage of $\mathrm{Pd}(\mathrm{II})$ by $\mathrm{ALi}-\mathrm{CY} 301$ can be ascribed to the difference in functional groups of organic anions (CY 272 ${ }^{-}$, D2EHPA ${ }^{-}, \mathrm{PC} 88 \mathrm{~A}^{-}$and $\mathrm{CY} 301^{-}$anions), which affects the interaction degree with $\mathrm{Pd}(\mathrm{II})$. Since Pd(II) is a soft acid according to hard soft acid base principle (HSAB), it has a stronger tendency to interact with soft bases such as sulfur atoms, rather than oxygen atoms (hard base). Along these lines, it can be deduced that $\mathrm{CY}_{301^{-}}$anions could have a weaker link with the ammonium cation center of ILs 
(where nitrogen atoms act like a hard base) compared to $\mathrm{CY}_{272}^{-}$, D2EHPA ${ }^{-}$and $\mathrm{PC} 88 \mathrm{~A}^{-}$ anions. This could facilitate the interaction between $\mathrm{CY}_{301^{-}}$anion $\mathrm{Pd}(\mathrm{II})$. The decrease in $\mathrm{Zn}$ (II) extraction by ALi-CY 301 with the increase of $\mathrm{H}_{2} \mathrm{SO}_{4}$ concentration could be due to the competition in the extraction with $\mathrm{H}_{2} \mathrm{SO}_{4}$, which can lead to the regeneration of Cyanex 301 and the formation of ILs such as ALi. $\mathrm{HSO}_{4}$. Besides, the high concentration of $\mathrm{H}_{2} \mathrm{SO}_{4}$ was able to depress the extraction ability of Cyanex 301 for $\mathrm{Zn}$ (II) [35]. The extraction reaction of $\mathrm{Pd}(\mathrm{II})$ by $\mathrm{ALi}-\mathrm{CY} 301$ can be expressed as:

$$
\mathrm{Pd}_{(\mathrm{a})}{ }^{2+}+2 \mathrm{HSO}_{4(\mathrm{a})}{ }^{-}+2\left[\mathrm{R}_{3} \mathrm{CH}_{3} \mathrm{~N}\right] \cdot[\mathrm{A}]_{(\mathrm{o})}=\mathrm{PdA}_{2(\mathrm{o})}+2\left[\mathrm{R}_{3} \mathrm{CH}_{3} \mathrm{~N}\right] \cdot\left[\mathrm{HSO}_{4}\right]_{(\mathrm{o})}
$$

where $\left[\mathrm{R}_{3} \mathrm{CH}_{3} \mathrm{~N}\right] \cdot[\mathrm{A}]$ denotes $\mathrm{ALi}-\mathrm{CY} 301$, and the subscripts (a) and (o) represent the aqueous and organic phases, respectively.
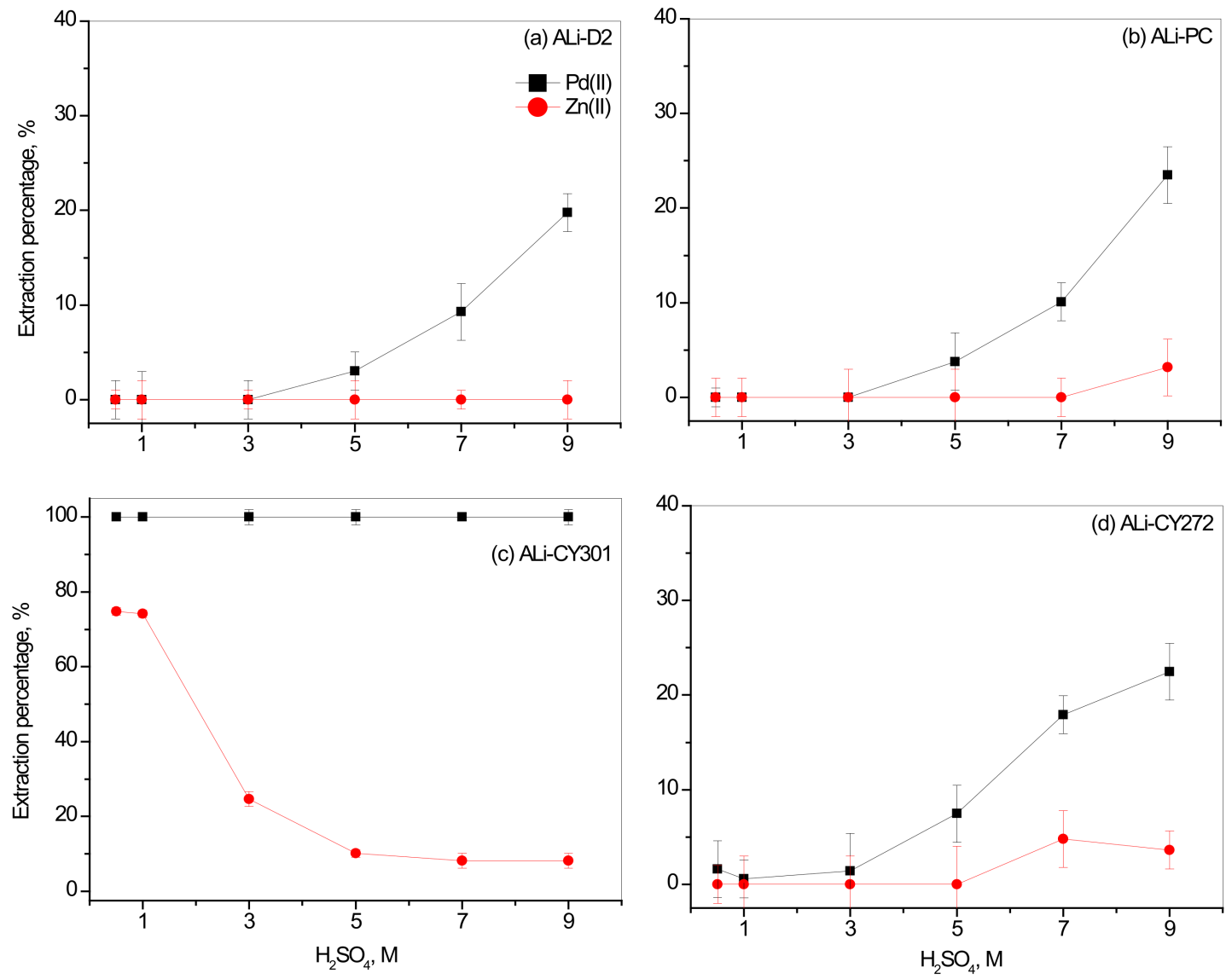

Figure 2. Effect of $\mathrm{H}_{2} \mathrm{SO}_{4}$ concentration on extraction of $\mathrm{Pd}(\mathrm{II})$ and $\mathrm{Zn}$ (II) by ILs: (a) ALi-D2, (b) ALi-PC, (c) ALi-CY301 and (d) ALi-CY272. Conditions: $[\mathrm{Pd}(\mathrm{II})]=100 \mathrm{mg} / \mathrm{L}$ and $[\mathrm{Zn}(\mathrm{II})]=500 \mathrm{mg} / \mathrm{L}$; [extractant $]=0.1 \mathrm{M}$, diluent: kerosene; modifier: decanol 10\% $v / v$. $\mathrm{A} / \mathrm{O}=1$.

In Figure 3, Pd(II) was completely extracted by ALi-LIX63 and ALi-LIX84, while Zn(II) extraction was negligible in the $\mathrm{H}_{2} \mathrm{SO}_{4}$ concentration range of 0.5 to $9 \mathrm{M}$. $\mathrm{Zn}$ (II) extraction by ALi-LIX84 increased from zero to $5.1 \%$ when $\mathrm{H}_{2} \mathrm{SO}_{4}$ concentration increased from 7 to $9 \mathrm{M}$. The extraction reaction of $\mathrm{Pd}(\mathrm{II})$ by ALi-LIX63 and ALi-LIX84 can be proposed as:

$$
\mathrm{H}^{+}+\mathrm{Pd}_{(\mathrm{a})}{ }^{2+}+3 \mathrm{HSO}_{4(\mathrm{a})}{ }^{-}+\left[\mathrm{R}_{3} \mathrm{CH}_{3} \mathrm{~N}\right] \cdot[\mathrm{A}]_{(\mathrm{o})}=\left[\mathrm{Pd}\left(\mathrm{HSO}_{4}\right)_{2}\right] \cdot 2 \mathrm{HA}_{(\mathrm{o})}+\left[\mathrm{R}_{3} \mathrm{CH}_{3} \mathrm{~N}\right] \cdot\left[\mathrm{HSO}_{4}\right]_{(\mathrm{o})}
$$

where $\left[\mathrm{R}_{3} \mathrm{CH}_{3} \mathrm{~N}\right] \cdot[\mathrm{A}]=\mathrm{ALi}-\mathrm{LIX63} / \mathrm{ALi}-\mathrm{LIX} 84 \mathrm{IL}$. 

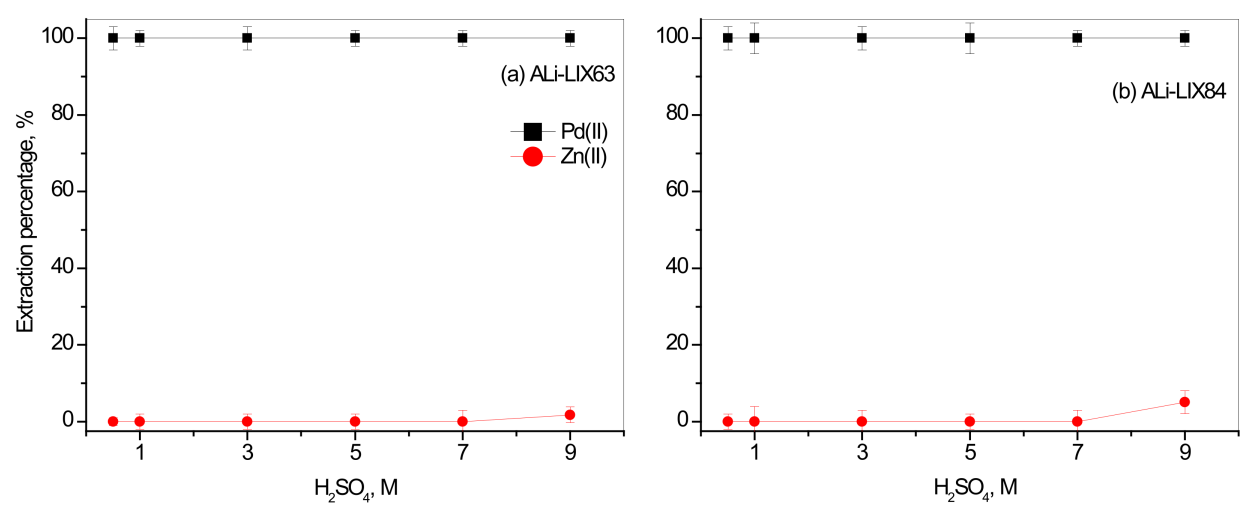

Figure 3. Effect of $\mathrm{H}_{2} \mathrm{SO}_{4}$ concentration on extraction of $\mathrm{Pd}(\mathrm{II})$ and $\mathrm{Zn}$ (II) by ILs: (a) ALi-LIX63 and (b) ALi-LIX84. Conditions: $[\mathrm{Pd}(\mathrm{II})]=100 \mathrm{mg} / \mathrm{L}$ and $[\mathrm{Zn}(\mathrm{II})]=500 \mathrm{mg} / \mathrm{L}$; [extractant $]=0.1 \mathrm{M}$, diluent: kerosene; modifier: decanol $10 \% v / v . \mathrm{A} / \mathrm{O}=1$.

The formation kinetics of $\mathrm{Pd}(\mathrm{II})$-hydrogen sulfate complexes is fast and depends on the concentration of sulfuric acid due to the nucleophilicity of $\mathrm{HSO}_{4}{ }^{-}$as an oxygen-donor ligand towards the $\mathrm{d}$ orbital of $\mathrm{Pd}(\mathrm{II})$ [24]. This may promote the selective extraction of Pd(II) over Zn(II).

Since anions such as $\mathrm{SCN}^{-}, \mathrm{Br}^{-}$or $\mathrm{I}^{-}$are more hydrophobic than $\mathrm{HSO}_{4}^{-}$, the complexes can be stabilized in the organic phase according to Hofmeister series [36]. Hence, synthesized ILs such as ALi-SCN, ALi-I and ALi-Br can provide the anions with which $\mathrm{Pd}$ (II) can form complexes such as $\mathrm{PdX}_{4}{ }^{2-}$ species (X: $\mathrm{SCN} / \mathrm{I} / \mathrm{Br}$ ), and these species can be selectively extracted to the IL organic phase. Consequently, these synthesized ILs can selectively extract $\mathrm{Pd}$ (II) over $\mathrm{Zn}$ (II) from sulfuric acid solution. As expected, $\mathrm{Pd}$ (II) was completely extracted regardless of the concentration of $\mathrm{H}_{2} \mathrm{SO}_{4}$. $\mathrm{Zn}$ (II) extraction by ALi-I and $\mathrm{ALi}-\mathrm{Br}$ was quite similar (see Figure 4). When $\mathrm{H}_{2} \mathrm{SO}_{4}$ concentration was less than $3 \mathrm{M}$, no $\mathrm{Zn}$ (II) was extracted by ALi-I. However, the extraction percentage of Zn(II) sharply increased from zero to completeness as $\mathrm{H}_{2} \mathrm{SO}_{4}$ concentration increased from 3 to $9 \mathrm{M}$. This may be attributed to the effect of $\mathrm{HSO}_{4}{ }^{-}$on the extraction of $\mathrm{Zn}(\mathrm{II})$ by ILs. Therefore, control of sulfuric acid concentration is important to separate $\mathrm{Pd}(\mathrm{II})$ and $\mathrm{Zn}$ (II) by ALi-I and $\mathrm{ALi}-\mathrm{Br}$.

In the extraction with ALi-SCN, $\mathrm{Zn}(\mathrm{II})$ was completely extracted when $\mathrm{H}_{2} \mathrm{SO}_{4}$ concentration was less than $3 \mathrm{M}$, but rapidly decreased to negligible as $\mathrm{H}_{2} \mathrm{SO}_{4}$ concentration increased from 5 to $9 \mathrm{M}$. The high extraction percentage of $\mathrm{Zn}(\mathrm{II})$ in the $\mathrm{H}_{2} \mathrm{SO}_{4}$ concentration range from 0.5 to $3 \mathrm{M}$ may be related to the formation of $\mathrm{Zn}(\mathrm{SCN})_{4}{ }^{2-}$ complexes that can be extracted to the organic phase $[37,38]$. However, the competitive extraction of hydrogen ions by ALi-SCN [39] may reduce the extraction of $\mathrm{Zn}$ (II) from concentrated $\mathrm{H}_{2} \mathrm{SO}_{4}$ solution. The extraction of hydrogen ions can lead to a decrease in the effective concentration of IL. The extraction reaction of Pd(II) by ALi-SCN, ALi-I and ALi-Br is proposed as Equation (7):

$\mathrm{Pd}_{(\mathrm{a})}{ }^{2+}+2 \mathrm{HSO}_{4(\mathrm{a})}{ }^{-}+4\left[\mathrm{R}_{3} \mathrm{CH}_{3} \mathrm{~N}\right] \cdot[\mathrm{X}]_{(\mathrm{o})}=\left[\left(\mathrm{R}_{3} \mathrm{CH}_{3} \mathrm{~N}\right)_{2}\right] \cdot\left[\mathrm{PdX}_{4}\right]_{(\mathrm{o})}+2\left[\mathrm{R}_{3} \mathrm{CH}_{3} \mathrm{~N}\right] \cdot\left[\mathrm{HSO}_{4}\right]_{(\mathrm{o})}$

where $\mathrm{X}$ represents $\mathrm{SCN}$, I and $\mathrm{Br}$.

Among some ILs tested in this work, the selective extraction of $\mathrm{Pd}(\mathrm{II})$ over $\mathrm{Zn}$ (II) by ALi-I and ALi-Br was possible when $\mathrm{H}_{2} \mathrm{SO}_{4}$ concentration was less than $3 \mathrm{M}$, while that by ALi-SCN and ALi-CY 301 was possible when $\mathrm{H}_{2} \mathrm{SO}_{4}$ concentration was higher than $7 \mathrm{M}$. Therefore, it might be concluded that ALi-LIX63 and ALi-LIX84 are the best candidates to separate $\mathrm{Pd}(\mathrm{II})$ over $\mathrm{Zn}(\mathrm{II})$ in the $\mathrm{H}_{2} \mathrm{SO}_{4}$ concentration range from 0.5 to $9 \mathrm{M}$. 


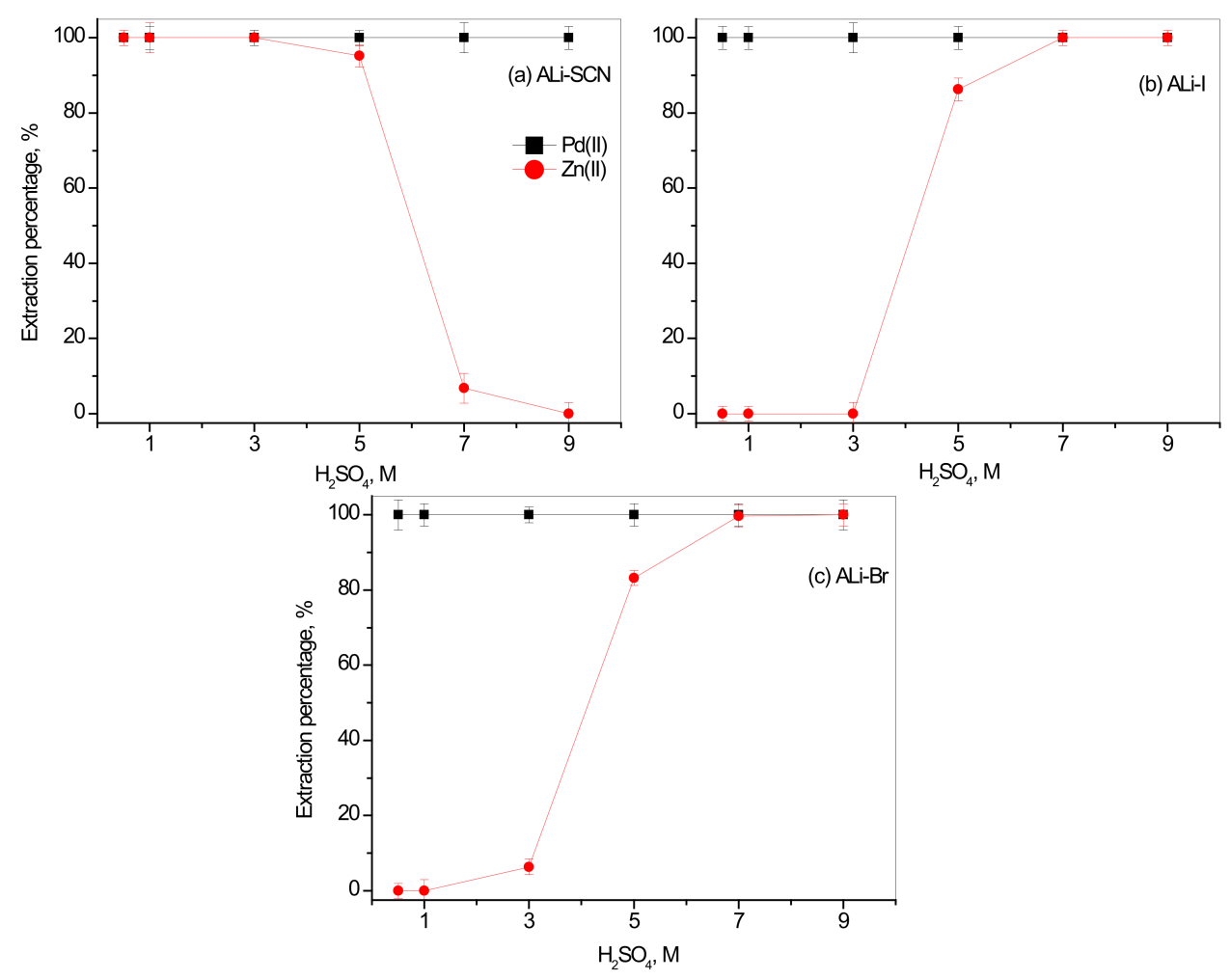

Figure 4. Effect of $\mathrm{H}_{2} \mathrm{SO}_{4}$ concentration on extraction of $\mathrm{Pd}(\mathrm{II})$ and $\mathrm{Zn}(\mathrm{II})$ by ILs: (a) ALi-SCN, (b) ALi-I and (c) ALi-Br. Conditions: $[\mathrm{Pd}(\mathrm{II})]=100 \mathrm{mg} / \mathrm{L}$ and $[\mathrm{Zn}(\mathrm{II})]=500 \mathrm{mg} / \mathrm{L}$; [extractant $]=0.1 \mathrm{M}$, diluent: kerosene; modifier: decanol $10 \% v / v . \mathrm{A} / \mathrm{O}=1$.

\subsection{Effect of Synthesized ILs Concentration on the Separation of Pd(II) over Zn(II)}

\subsubsection{Effect of Concentration of Synthesized ILs with Organic Anions}

To investigate the effect of IL concentration on the selective extraction of $\mathrm{Pd}$ (II) over $\mathrm{Zn}$ (II), the concentration of ILs was varied from 0.001 to $0.1 \mathrm{M}$. The synthetic leaching solution contained $100 \mathrm{mg} / \mathrm{L}$ of $\mathrm{Pd}(\mathrm{II})$ and $500 \mathrm{mg} / \mathrm{L}$ of $\mathrm{Zn}$ (II). Based on the data in Section 3.1, $\mathrm{H}_{2} \mathrm{SO}_{4}$ concentration was adjusted for the complete separation of $\mathrm{Pd}(\mathrm{II})$ and $\mathrm{Zn}$ (II): namely, $7 \mathrm{M} \mathrm{H}_{2} \mathrm{SO}_{4}$ for ALi-CY301, and $0.5 \mathrm{M} \mathrm{H}_{2} \mathrm{SO}_{4}$ for ALi-LIX63 and ALi-LIX84. In these experiments, the volume ratio of organic to aqueous phase was unity. Figure $5 \mathrm{a}$ shows that Pd(II) was completely extracted by ALi-CY301, while the extraction of $\mathrm{Zn}$ (II) increased from zero to $8.1 \%$ with the increase of $\mathrm{ALi}-\mathrm{CY} 301$ concentration from 0.001 to $0.1 \mathrm{M}$. Therefore, $0.001 \mathrm{M}$ ALi-CY301 was selected for complete separation of Pd(II) over $\mathrm{Zn}$ (II). The increase of $\mathrm{Zn}$ (II) co-extraction might be related to the strong affinity of $\mathrm{Zn}$ (II) toward CY301- anions according to Lewis acid base theory [35], since $\mathrm{Zn}$ (II) ion is an electron-pair acceptor which has a strong tendency to accept the nonbonding electron pairs from the functional group of $\mathrm{CY}_{301}{ }^{-}$. Furthermore, their effective interaction can be accelerated by the increase of $\mathrm{ALi}-\mathrm{CY} 301$ concentration. Therefore, it is essential to control ALi-CY301 concentration for the selective extraction of $\mathrm{Pd}(\mathrm{II})$.

Figure $5 \mathrm{~b}, \mathrm{c}$ display selective extraction of $\mathrm{Pd}(\mathrm{II})$ over $\mathrm{Zn}$ (II) by ALi-LIX63 and ALiLIX84 from $0.5 \mathrm{M} \mathrm{H}_{2} \mathrm{SO}_{4}$ solution. The extraction percentage of $\mathrm{Pd}(\mathrm{II})$ sharply increased from $23.7 \%$ to $100 \%$ and from $6.3 \%$ to $100 \%$ when the concentration of both ALi-LIX63 (Figure 5b) and ALi-LIX84 (Figure 5c) increased from 0.001 to $0.005 \mathrm{M}$. Zn(II) was not extracted at all by either ALi-LIX63 or ALi-LIX84 in this condition. Hence, among three synthesized ILs with organic anions, ALi-LIX63 and ALi-LIX84 exhibited selectivity and high efficiency for the separation of $\mathrm{Pd}(\mathrm{II})$ and $\mathrm{Zn}(\mathrm{II})$. This was explained by the selectivity of the organic anions of LIX 63 and LIX 84 for Pd(II) compared to the Cyanex 301 anion. It can be verified from the reported data that these cationic extractants show selectivity for Pd(II) extraction $[4,6,12]$. When the concentration of LIX 84 and ALi-LIX84 was the 
same $(0.1 \mathrm{M})$, the extraction percentage of $\mathrm{Pd}(\mathrm{II})$ was $80 \%$, while complete extraction was possible by ALi-LIX84. Therefore, it might be said that the synthesized ILs can enhance the extraction of $\mathrm{Pd}(\mathrm{II})$ compared to the cationic extractants.

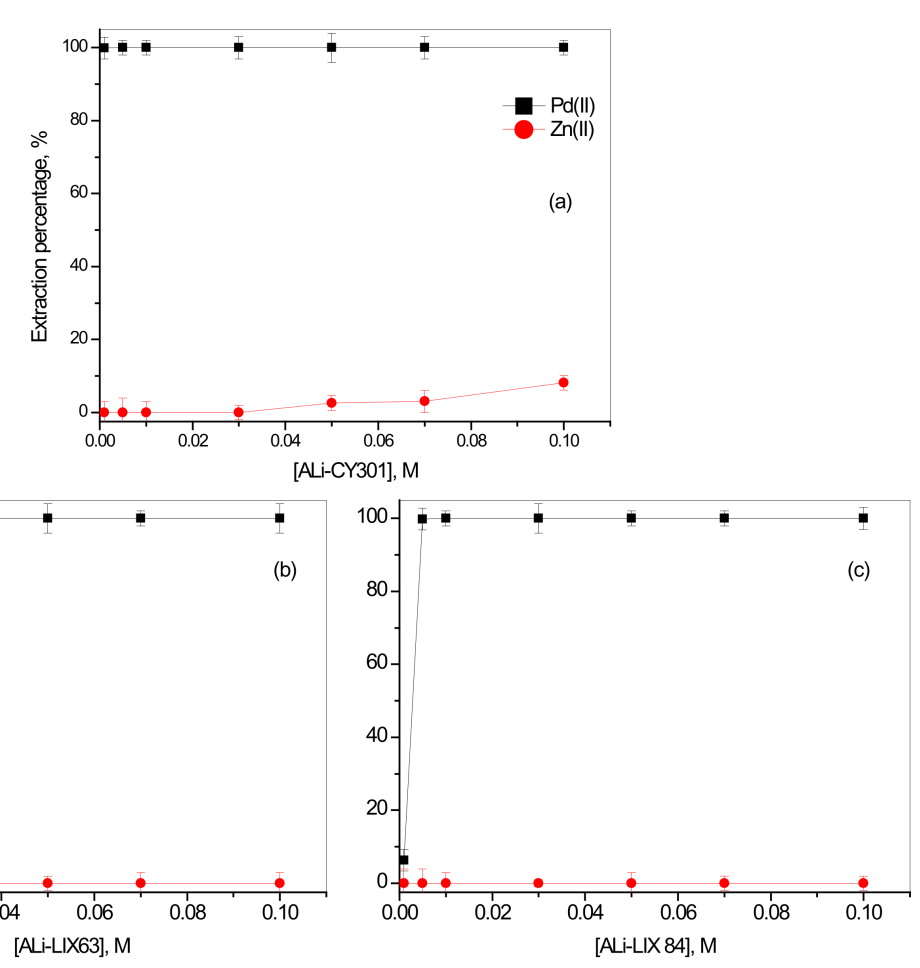

Figure 5. Effect of (a) ALi-CY301, (b) ALi-LIX63 and (c) ALi-LIX84 concentration on extraction of $\mathrm{Pd}(\mathrm{II})$ and $\mathrm{Zn}(\mathrm{II})$. Conditions: [extractant] = 0.001-0.1 M, diluent: kerosene; modifier: decanol $10 \% v / v . \mathrm{A} / \mathrm{O}=1,(\mathbf{a}) 7 \mathrm{M} \mathrm{H}_{2} \mathrm{SO}_{4},(\mathbf{b}, \mathbf{c}) 0.5 \mathrm{M} \mathrm{H}_{2} \mathrm{SO}_{4}[\mathrm{Pd}(\mathrm{II})]=100 \mathrm{mg} / \mathrm{L}$ and $[\mathrm{Zn}(\mathrm{II})]=500 \mathrm{mg} / \mathrm{L}$.

\subsubsection{Effect of Concentration of Synthesized ILs with Inorganic Anions}

In these experiments, IL concentration was varied from 0.001 to $0.1 \mathrm{M}$ and the concentration of $\mathrm{H}_{2} \mathrm{SO}_{4}$ in synthetic leaching solution was controlled for each employed IL (0.5 $\mathrm{M} \mathrm{H}_{2} \mathrm{SO}_{4}$ for ALi-I and ALi-Br and $9 \mathrm{M}$ for ALi-SCN). The concentrations of Pd(II) and $\mathrm{Zn}(\mathrm{II})$ in the synthetic leaching solution were 100 and $500 \mathrm{mg} / \mathrm{L}$, respectively. The volume ratio of the organic to aqueous phase was kept at unity. The results indicated that $\mathrm{Pd}(\mathrm{II})$ extraction percentage is a function of ALi-SCN concentration. As seen in Figure 6a, the extraction percentage of $\mathrm{Pd}(\mathrm{II})$ increased from $64 \%$ to $100 \%$ when the concentration of ALi-SCN increased from 0.001 to $0.005 \mathrm{M}$, and then remained constant with the increase of ALi-SCN. Zn(II) was not extracted at all in these conditions.

Figure $6 \mathrm{~b}, \mathrm{c}$ show that the extraction percentage of $\mathrm{Pd}(\mathrm{II})$ increased from $63.6 \%$ to $100 \%$ and from $39.9 \%$ to $100 \%$ when the concentration of $\mathrm{ALi}-\mathrm{I}$ and $\mathrm{ALi}-\mathrm{Br}$ increased from 0.001 to $0.005 \mathrm{M}$, then remained constant with the increase of ILs concentration. In these conditions, no $\mathrm{Zn}$ (II) was extracted and complete separation of $\mathrm{Pd}(\mathrm{II})$ and $\mathrm{Zn}$ (II) was possible. Our results indicate that both the synthesized ILs with organic (ALi-CY301, ALiLIX63 and ALi-LIX84) and inorganic anions (ALi-SCN, ALi-I and ALi-Br) are effective in separating $\mathrm{Pd}(\mathrm{II})$ and $\mathrm{Zn}(\mathrm{II})$ from sulfuric acid solutions. Herein, ALi-I and ALi-Br are the best as an extractant for separating $\mathrm{Pd}(\mathrm{II})$ and $\mathrm{Zn}(\mathrm{II})$ when $\mathrm{H}_{2} \mathrm{SO}_{4}$ concentration is lower than $3 \mathrm{M}$, while ALi-CY301 and ALi-SCN are good when $\mathrm{H}_{2} \mathrm{SO}_{4}$ concentration is higher than $7 \mathrm{M}$. Especially, ALi-LIX63 and ALi-LIX84 can selectively extract Pd(II) from $\mathrm{H}_{2} \mathrm{SO}_{4}$ concentration in the range from 0.5 to $9 \mathrm{M}$, while $\mathrm{Zn}$ (II) was not extracted at all. 


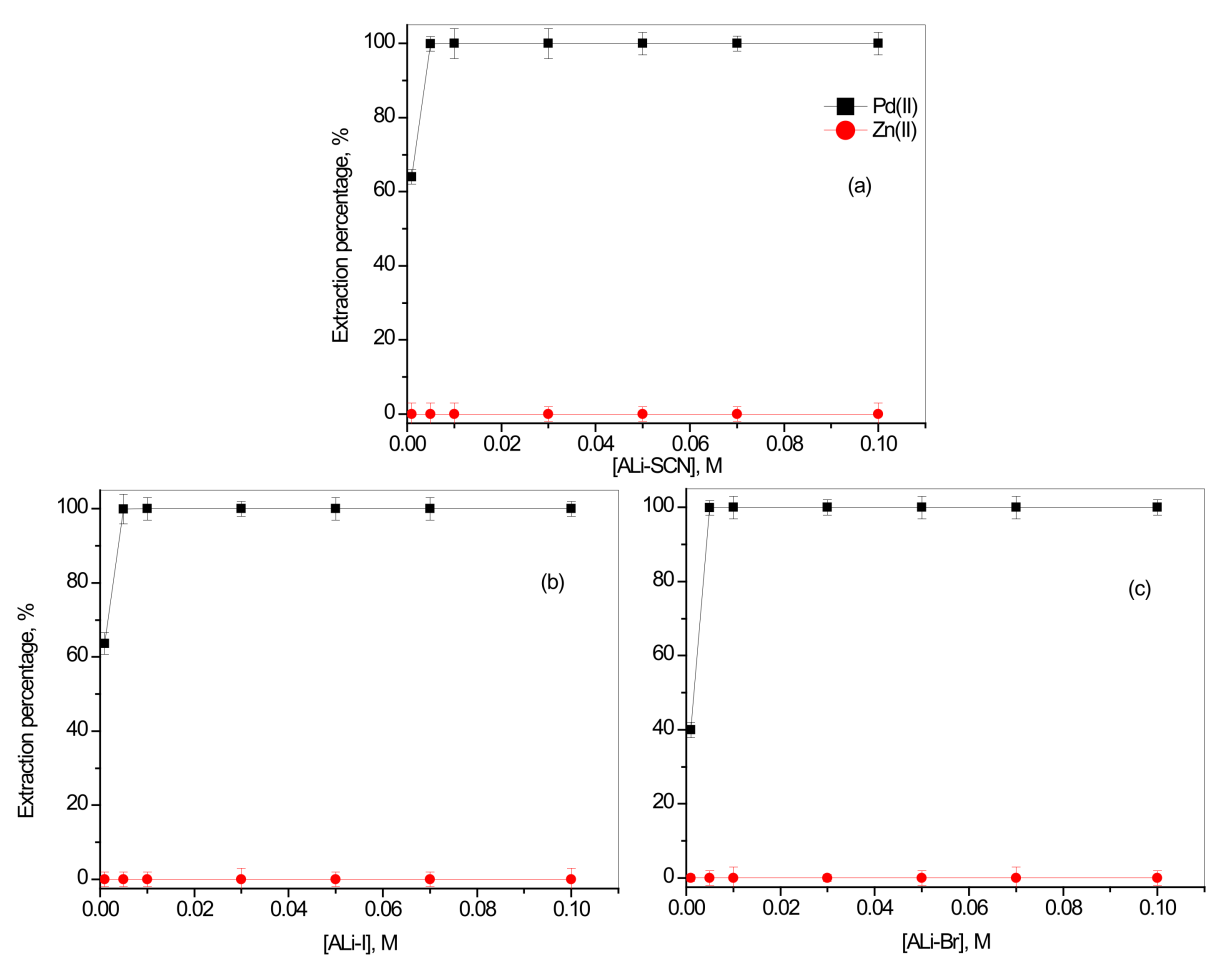

Figure 6. Effect of (a) ALi-SCN, (b) ALi-I and (c) ALi-Br concentration on extraction of $\mathrm{Pd}(\mathrm{II})$ and $\mathrm{Zn}(\mathrm{II})$. Conditions: [extractant] $=0.001-0.1 \mathrm{M}$, diluent: kerosene; modifier: decanol $10 \% \mathrm{v} / \mathrm{v} . \mathrm{A} / \mathrm{O}=1$, (a) $9 \mathrm{M} \mathrm{H}_{2} \mathrm{SO}_{4}$, (b,c) $0.5 \mathrm{M} \mathrm{H}_{2} \mathrm{SO}_{4} ;[\mathrm{Pd}(\mathrm{II})]=100 \mathrm{mg} / \mathrm{L}$ and $[\mathrm{Zn}(\mathrm{II})]=500 \mathrm{mg} / \mathrm{L}$.

\subsection{Stripping of Pd(II)}

\subsubsection{Preliminary Stripping Experiments}

Stripping is one of the important steps in the solvent extraction process, and thus several stripping agents were tested to recover Pd(II) from the loaded IL phases. The $\mathrm{Pd}$ (II) in the loaded synthesized ILs was obtained by contacting $0.005 \mathrm{M}$ ILs, except for $\mathrm{ALi}-\mathrm{CY} 301$, to the aqueous solution containing $100 \mathrm{mg} / \mathrm{L}$ of $\mathrm{Pd}(\mathrm{II})$ and $500 \mathrm{mg} / \mathrm{L}$ of $\mathrm{Zn}$ (II) at certain $\mathrm{H}_{2} \mathrm{SO}_{4}$ concentrations. In the case of $\mathrm{ALi}-\mathrm{CY} 301$, its concentration was controlled to $0.001 \mathrm{M}$. Based on the best condition for complete separation of $\mathrm{Pd}$ (II) over $\mathrm{Zn}$ (II), the concentration of $\mathrm{H}_{2} \mathrm{SO}_{4}$ in synthetic leaching solution was adjusted for each employed IL as follows: $7 \mathrm{M} \mathrm{H}_{2} \mathrm{SO}_{4}$ for ALi-CY301, $0.5 \mathrm{M} \mathrm{H}_{2} \mathrm{SO}_{4}$ for ALi-LIX63, ALi-LIX84, ALi-I and $\mathrm{ALi}-\mathrm{Br}$ and $9 \mathrm{M}$ for $\mathrm{ALi}-\mathrm{SCN}$. The volume ratio of organic to aqueous phase was unity. The concentration of $\mathrm{Pd}(\mathrm{II})$ in the loaded organic phase of the ILs was $100 \mathrm{mg} / \mathrm{L}$, and no $\mathrm{Zn}$ (II) was extracted at these conditions.

It has been reported that $\mathrm{NH}_{3}$ solution and the mixture of $\mathrm{HCl}$ and thiourea are efficient stripping agents for $\mathrm{Pd}(\mathrm{II})$ from the loaded phases of $\mathrm{ALi}-\mathrm{I}$ and $\mathrm{ALi}-\mathrm{Br}$, as well as LIX $63[4,9]$. Therefore, these agents and single thiourea as well as acidic solutions $\left(\mathrm{HCl}, \mathrm{H}_{2} \mathrm{SO}_{4}\right)$ were employed to investigate $\mathrm{Pd}(\mathrm{II})$ stripping efficiency. Table 3 displays the stripping percentage of $\mathrm{Pd}(\mathrm{II})$ from the corresponding loaded IL phase. Among the tested stripping agents, $\mathrm{NH}_{3}$ solution exhibited the highest stripping capacity for $\mathrm{Pd}(\mathrm{II})$ from ALi-SCN (5\%), ALi-I (89.7\%) and ALi-Br (100\%), whereas a mixture of $0.1 \mathrm{M} \mathrm{HCl}$ and $0.5 \mathrm{M}$ thiourea showed a quantitative stripping of $\mathrm{Pd}$ (II) from the loaded ALi-LIX63 and ALi-LIX84. However, the stripping of Pd(II) from the loaded ALi-CY 301 was very difficult $(<1 \%)$. This can be attributed to the strong affinity between $\mathrm{Pd}(\mathrm{II})$ and sulfur atoms of Cyanex 301 on the basis of the HSAB principle. The limited stripping of $\mathrm{Pd}(\mathrm{II})$ with $\mathrm{NH}_{3}$ solution from the loaded ALi-SCN may be related to the co-extraction of hydrogen ions from concentrated $\mathrm{H}_{2} \mathrm{SO}_{4}$ solution [39]. 
Table 3. Stripping efficiency of Pd(II) using diverse reagents ([IL] except ALi-CY301 = 0.005 M, [ALi-CY301] = 0.001 M, $\mathrm{A} / \mathrm{O}=1,[\mathrm{Pd}]$ in the loaded phase was $100 \mathrm{mg} / \mathrm{L})$.

\begin{tabular}{|c|c|c|c|c|c|c|}
\hline \multirow{2}{*}{ Stripping Agent } & \multicolumn{6}{|c|}{ Loaded Organic Phase, Stripping Percentage (\%S) } \\
\hline & ALi-C301 & ALi-LIX63 & ALi-LIX84 & ALi-I & $\mathrm{ALi}-\mathrm{Br}$ & ALi-SCN \\
\hline $5 \% \mathrm{NH}_{3}$ & 0.6 & 0.0 & 2.1 & 89.7 & 100.0 & 5.0 \\
\hline $0.1 \mathrm{M} \mathrm{HCl}$ & 0.0 & 0.0 & 0.0 & 0.3 & 2.4 & 0.0 \\
\hline $0.1 \mathrm{M} \mathrm{H}_{2} \mathrm{SO}_{4}$ & 0.0 & 0.0 & 0.1 & 0.0 & 0.0 & 0.0 \\
\hline $0.5 \mathrm{M}$ thioure & 0.5 & 2.9 & 2.2 & 2.5 & 9.0 & 1.1 \\
\hline $0.1 \mathrm{M} \mathrm{HCl}+0.5 \mathrm{M}$ thioure & 0.8 & 13.5 & 14.1 & 11.4 & 17.9 & 1.2 \\
\hline $0.1 \mathrm{M} \mathrm{H}_{2} \mathrm{SO}_{4}+0.5 \mathrm{M}$ thioure & 0.2 & 0.3 & 0.3 & 0.0 & 1.0 & 0.6 \\
\hline
\end{tabular}

3.3.2. Stripping of Pd(II) from Loaded Organic Phase of Synthesized ILs with Organic Anions

To investigate the effect of $\mathrm{HCl}$ and thiourea concentration on stripping of $\mathrm{Pd}(\mathrm{II})$ from the loaded ALi-LIX63 and ALi-LIX84 phases, their concentrations were varied from 0.1 to $5 \mathrm{M}$ and 0.1 to $0.5 \mathrm{M}$, respectively. The results in Table 4 reveal that the mixture of $0.5 \mathrm{M}$ $\mathrm{HCl}$ and $0.5 \mathrm{M}$ thiourea can completely strip Pd(II) from the loaded ALi-LIX63, while complete stripping of $\mathrm{Pd}(\mathrm{II})$ from the loaded ALi-LIX84 was possible by the mixture of $0.5 \mathrm{M} \mathrm{HCl}$ and thiourea, whose concentration was in the range from 0.1 to $0.5 \mathrm{M}$. The stripping percentage of $\mathrm{Pd}(\mathrm{II})$ decreased when $\mathrm{HCl}$ concentration in the mixture was higher than $1 \mathrm{M}$. This phenomenon may be related to the stability of the $\mathrm{Pd}(\mathrm{II})$-chloro complexes in the concentrated $\mathrm{HCl}$ solution, resulting in the extraction of $\mathrm{Pd}$-chloro complexes to the organic phase. The stripping reaction of $\mathrm{Pd}(\mathrm{II})$ from the loaded ILs using a mixture of $\mathrm{HCl}$ and thiourea can be represented as follows:

$\mathrm{Pd}\left(\mathrm{HSO}_{4}\right)_{2} \cdot 2 \mathrm{HA}_{(\mathrm{o})}+2\left[\mathrm{R}_{3} \mathrm{CH}_{3} \mathrm{~N}\right] \cdot\left[\mathrm{HSO}_{4}\right]_{(\mathrm{o})}+2\left(\mathrm{NH}_{2}\right)_{2} \mathrm{CS}_{(\mathrm{a})}=\mathrm{Pd}\left(\mathrm{HSO}_{4}\right)_{2}\left[\left(\mathrm{NH}_{2}\right)_{2} \mathrm{CS}_{2(\mathrm{a})}+2\left[\mathrm{R}_{3} \mathrm{CH}_{3} \mathrm{~N}\right] \cdot[\mathrm{A}]_{(\mathrm{o})}+2 \mathrm{H}_{2} \mathrm{SO}_{4(\mathrm{a})}\right.$

where HA denotes LIX 63/LIX 84.

Table 4. Effect of $\mathrm{HCl}$ and thiourea concentration on stripping of Pd(II) from ALi-LIX63 and ALi-LIX84 loaded phases ([IL] $=0.005 \mathrm{M}, \mathrm{A} / \mathrm{O}=1,[\mathrm{Pd}]$ in the loaded phase was $100 \mathrm{mg} / \mathrm{L})$.

\begin{tabular}{|c|c|c|c|c|c|}
\hline \multirow{2}{*}{ Stripping Agent } & \multicolumn{2}{|c|}{ Pd(II) Stripping Percentage (\%S) } & \multirow{2}{*}{ Stripping Agent } & \multicolumn{2}{|c|}{ Pd(II) Stripping Percentage $(\% \mathrm{~S})$} \\
\hline & ALi-LIX63 & ALi-LIX84 & & ALi-LIX63 & ALi-LIX84 \\
\hline $0.1 \mathrm{M} \mathrm{HCl}+0.5 \mathrm{M}$ thiourea & 13.5 & 14.1 & $0.5 \mathrm{M} \mathrm{HCl}+0.1 \mathrm{M}$ thiourea & 81.8 & 100 \\
\hline $0.5 \mathrm{M} \mathrm{HCl}+0.5 \mathrm{M}$ thiourea & 100 & 100 & $0.5 \mathrm{M} \mathrm{HCl}+0.2 \mathrm{M}$ thiourea & 91.0 & 100 \\
\hline $1 \mathrm{M} \mathrm{HCl}+0.5 \mathrm{M}$ thiourea & 100 & 100 & $0.5 \mathrm{M} \mathrm{HCl}+0.3 \mathrm{M}$ thiourea & 94.1 & 100 \\
\hline $3 \mathrm{M} \mathrm{HCl}+0.5 \mathrm{M}$ thiourea & 65.3 & 65.9 & $0.5 \mathrm{M} \mathrm{HCl}+0.4 \mathrm{M}$ thiourea & 96.9 & 100 \\
\hline $5 \mathrm{M} \mathrm{HCl}+0.5 \mathrm{M}$ thiourea & 34.4 & 45.0 & $0.5 \mathrm{M} \mathrm{HCl}+0.5 \mathrm{M}$ thiourea & 100 & 100 \\
\hline
\end{tabular}

Since stripping of $\mathrm{Pd}(\mathrm{II})$ from the loaded ALi-CY 301 was difficult, aqua regia solutions with several dilution degrees were employed, and $90 \%$ of $\operatorname{Pd}(\mathrm{II})$ was stripped from the loaded Ali-CY301 by aqua regia diluted 1.5 times.

3.3.3. Stripping of Pd(II) from Loaded Organic Phase of Synthesized ILs with Inorganic Anions

According to preliminary stripping experiments, $\mathrm{NH}_{3}$ solution is appropriate to strip $\mathrm{Pd}$ (II) from the loaded phase of ILs with inorganic anions. To investigate the effect of $\mathrm{NH}_{3}$ concentration on the stripping of $\mathrm{Pd}(\mathrm{II})$ from the loaded ALi-I and ALi-Br phases, the concentration of $\mathrm{NH}_{3}$ was changed from 0.5 to $3 \mathrm{M}$ (see Table 5). The stripping percentage of $\mathrm{Pd}(\mathrm{II})$ from the loaded ALi-Br was higher than that from the loaded ALi-I phase. Pd(II) from ALi-Br was completely stripped by $0.5 \mathrm{M} \mathrm{NH}_{3}$, while only $91.4 \%$ of $\mathrm{Pd}(\mathrm{II})$ was 
stripped from the loaded ALi-I. The stripping reaction of $\mathrm{Pd}(\mathrm{II})$ from the loaded ALi-I and ALi-Br with $\mathrm{NH}_{3}$ solution can be proposed as:

$$
\left(\mathrm{R}_{3} \mathrm{CH}_{3} \mathrm{~N}\right)_{2}\left[\mathrm{PdX}_{4}\right]_{(\mathrm{o})}+2\left[\mathrm{R}_{3} \mathrm{CH}_{3} \mathrm{~N}\right]\left[\mathrm{HSO}_{4}\right]_{(\mathrm{o})}+4 \mathrm{NH}_{4} \mathrm{OH}_{(\mathrm{a})}=4\left[\mathrm{R}_{3} \mathrm{CH}_{3} \mathrm{~N}\right][\mathrm{X}]_{(\mathrm{o})}+\left[\mathrm{Pd}\left(\mathrm{NH}_{3}\right)_{4}\right]\left(\mathrm{HSO}_{4}\right)_{2(\mathrm{a})}+4 \mathrm{H}_{2} \mathrm{O}
$$

where $\mathrm{X}$ denotes $\mathrm{Br}$ and $\mathrm{I}$.

Table 5. Effect of $\mathrm{NH}_{3}$ concentration on stripping of $\mathrm{Pd}(\mathrm{II})$ from ALi-I and ALi-Br loaded phases $([\mathrm{IL}]=0.005 \mathrm{M}, \mathrm{A} / \mathrm{O}=1,[\mathrm{Pd}]$ in the loaded phase was $100 \mathrm{mg} / \mathrm{L}$ ).

\begin{tabular}{ccc}
\hline \multirow{2}{*}{ Stripping Agent $\mathrm{NH}_{3}, \mathbf{M}$} & \multicolumn{2}{c}{ Loaded Organic Phase, \% } \\
\cline { 2 - 3 } & $\mathbf{A L i}-\mathbf{I}$ & $\mathbf{A L i}-\mathbf{B r}$ \\
\hline 0.5 & 91.4 & 100 \\
\hline 1 & 89.6 & 100 \\
\hline 2 & 88.5 & 100 \\
\hline 3 & 86.5 & 100 \\
\hline
\end{tabular}

The stripping percentage of $\mathrm{Pd}$ (II) by a single $\mathrm{NH}_{3}$ solution from the loaded ALi-SCN was low (5\%), however, the use of a concentrated $\mathrm{NH}_{3}$ solution as a stripping agent is unfavorable owing to the probable decomposition of ILs [40]. Therefore, $\mathrm{NH}_{4} \mathrm{Cl}$ was added to $5 \% \mathrm{NH}_{3}$ solution to enhance the stripping of $\mathrm{Pd}(\mathrm{II})$. The obtained results show that $98.4 \%$ of $\mathrm{Pd}$ (II) was stripped from the loaded ALi-SCN by the mixture of $1 \mathrm{M} \mathrm{NH}_{4} \mathrm{Cl}$ and $5 \% \mathrm{NH}_{3}$ solution. When the concentration of $\mathrm{NH}_{4} \mathrm{Cl}$ was higher than $1 \mathrm{M}$, the excess concentration of chloride ions in the stripping solution adversely affected the stripping of $\mathrm{Pd}(\mathrm{II})$ due to the extraction of the $\mathrm{Pd}(\mathrm{II})$-chloro complex.

Table 6 shows that synthesized ILs such as ALi-CY301, ALi-LIX63, ALi-LIX84, ALi$\mathrm{SCN}, \mathrm{ALi}-\mathrm{I}$ and $\mathrm{ALi}-\mathrm{Br}$ can be considered as potential extractants for separation of $\mathrm{Pd}(\mathrm{II})$ over $\mathrm{Zn}$ (II) from sulfuric acid solutions. The selective extraction efficiency of $\mathrm{Pd}$ (II) over $\mathrm{Zn}$ (II) by ILs depends on $\mathrm{H}_{2} \mathrm{SO}_{4}$ concentrations. It is noticeable that both ALi-LIX63 and ALi-LIX84 can selectively extract $\mathrm{Pd}(\mathrm{II})$ regardless of $\mathrm{H}_{2} \mathrm{SO}_{4}$ concentration in the range from 0.5 to $9 \mathrm{M}$. On the other hand, the difference in the complex formation degree between $\mathrm{Pd}(\mathrm{II})$ and $\mathrm{Zn}(\mathrm{II})$ with inorganic anions $\left(\mathrm{SCN}^{-}, \mathrm{I}^{-}, \mathrm{Br}^{-}\right)$significantly contributes to the complete separation of two metal ions from sulfuric acid solutions by ILs such as ALi-SCN, $\mathrm{ALi}-\mathrm{I}$ and $\mathrm{ALi}-\mathrm{Br}$. The complete stripping of $\mathrm{Pd}(\mathrm{II})$ from the loaded ILs was possible by employing either the mixture of $\mathrm{HCl}$ and thiourea or $\mathrm{NH}_{3}$ solution. These data indicated that a simple solvent extraction process using the synthesized ILs can be applied for the separation of $\mathrm{Pd}(\mathrm{II})$ and $\mathrm{Zn}$ (II) from the sulfuric acid leaching solutions of cemented Pd.

\subsection{The Separation of Pd(II) over Zn(II) from Real Leaching Solution of Cemented Pd}

The cemented Pd was obtained from the spent electroplating solutions by cementation with $\mathrm{Zn}$ metal powder. The cemented Pd was washed with diluted sulfuric acid solution and then the residues were dissolved at the optimum leaching condition [2], namely, a mixture of $5 \mathrm{M} \mathrm{H}_{2} \mathrm{SO}_{4}$ and $1.5 \% \mathrm{NaClO}$, pulp density: $2 \mathrm{~g} / \mathrm{L}, 1 \mathrm{~h}$, and $25^{\circ} \mathrm{C}$. At this condition, the $\mathrm{Pd}$ and $\mathrm{Zn}$ metal in the cemented Pd were completely dissolved. The concentrations of $\mathrm{Pd}$ (II) and $\mathrm{Zn}(\mathrm{II})$ in the real leaching solution were 1926 and $74 \mathrm{mg} / \mathrm{L}$, respectively.

From our data on the separation of Pd(II) and Zn(II) by several ILs, ALi-LIX63 and $\mathrm{ALi}-\mathrm{LIX} 84$ were selected as extractants and employed to the real leaching solution of the cemented Pd. The concentration of these two ILs was varied from 0.005 to $0.2 \mathrm{M}$ and the volume ratio of the two phases was fixed at unity. Figure 7 shows that both $\mathrm{Pd}(\mathrm{II})$ and $\mathrm{Zn}$ (II) was extracted by (a) ALi-LIX63 and (b) ALi-LIX84, and the extraction percentage is a function of ILs' concentration. The obtained results indicated that the extraction percentage of $\mathrm{Pd}$ (II) and $\mathrm{Zn}$ (II) increased from $51.4 \%$ (40.5\%) to $99.5 \%$ (98.7\%) and from $22.3 \%(22.1 \%)$ to $100 \%(100 \%)$ respectively, when the concentration of ALi-LIX63 (ALi-LIX84) increased from 0.005 to $0.2 \mathrm{M}$. 
Table 6. Summary on the separation of Pd(II) and Zn(II) from sulfuric acid solution by using synthesized ILs in this work ([Pd(II)] = $100 \mathrm{mg} / \mathrm{L}$ and [Zn(II)] = 500 mg/L).

\begin{tabular}{|c|c|c|c|c|c|}
\hline IL Extractant & {$\left[\mathrm{H}_{2} \mathrm{SO}_{4}\right], \mathrm{M}$} & $\begin{array}{c}\text { Extraction } \\
\text { Percentage }(\% \mathrm{E})\end{array}$ & Stripping Agents & Stripping Percentage $(\% \mathrm{~S})$ & Separation Efficiency \\
\hline 0.1 M ALi-D2 & 9 & $\begin{array}{l}\text { Pd: } 19.8 \\
\text { Zn: } 0\end{array}$ & - & - & $\begin{array}{l}\text { Low extraction percentage } \\
\text { Complete separation }\end{array}$ \\
\hline 0.1 M ALi-CY272 & 5 & $\begin{array}{l}\text { Pd: } 7.5 \\
\text { Zn: } 0\end{array}$ & - & - & $\begin{array}{l}\text { Low extraction percentage } \\
\text { Complete separation }\end{array}$ \\
\hline $0.1 \mathrm{M}$ ALi-PC & 7 & $\begin{array}{l}\text { Pd: } 10 \\
\text { Zn: } 0\end{array}$ & - & - & As above \\
\hline 0.001 M ALi-CY301 & $7-9$ & $\begin{array}{l}\text { Pd: } 100 \\
\text { Zn: } 0\end{array}$ & Aqua regia diluted 1.5 times & 90.6 & $\begin{array}{l}\text { High extraction percentage of } \mathrm{Pd}(\mathrm{II}) \text { but control } \\
\text { of IL concentration to low is necessary to avoid } \\
\text { co-extraction of a small amount of } \mathrm{Zn}(\mathrm{II}) \text {. } \\
\text { High separation }\end{array}$ \\
\hline 0.005 M ALi-LIX63 & $0.5-9$ & $\begin{array}{l}\text { Pd: } 100 \\
\text { Zn: } 0\end{array}$ & $\begin{array}{c}\text { Mixture of } 0.5 \mathrm{M} \mathrm{HCl} \text { and } \\
0.5 \mathrm{M} \text { Thiourea }\end{array}$ & 100 & $\begin{array}{l}\text { High extraction and stripping percentage } \\
\text { Complete separation }\end{array}$ \\
\hline 0.005 M ALi-LIX84 & $0.5-9$ & $\begin{array}{l}\text { Pd: } 100 \\
\text { Zn: } 0\end{array}$ & $\begin{array}{c}\text { Mixture of } 0.5 \mathrm{M} \mathrm{HCl} \text { and } \\
0.1 \mathrm{M} \text { Thiourea }\end{array}$ & 100 & As above \\
\hline $0.005 \mathrm{M} \mathrm{ALi}-\mathrm{Br}$ & $0.5-1$ & $\begin{array}{l}\text { Pd: } 100 \\
\text { Zn: } 0\end{array}$ & $0.5 \mathrm{M} \mathrm{NH}_{3}$ & 100 & As above \\
\hline 0.005 M ALi-SCN & 9 & $\begin{array}{l}\text { Pd: } 100 \\
\text { Zn: } 0\end{array}$ & $1 \mathrm{M} \mathrm{NH}_{4} \mathrm{Cl}$ and $5 \% \mathrm{NH}_{3}$ & 98.4 & As above \\
\hline
\end{tabular}



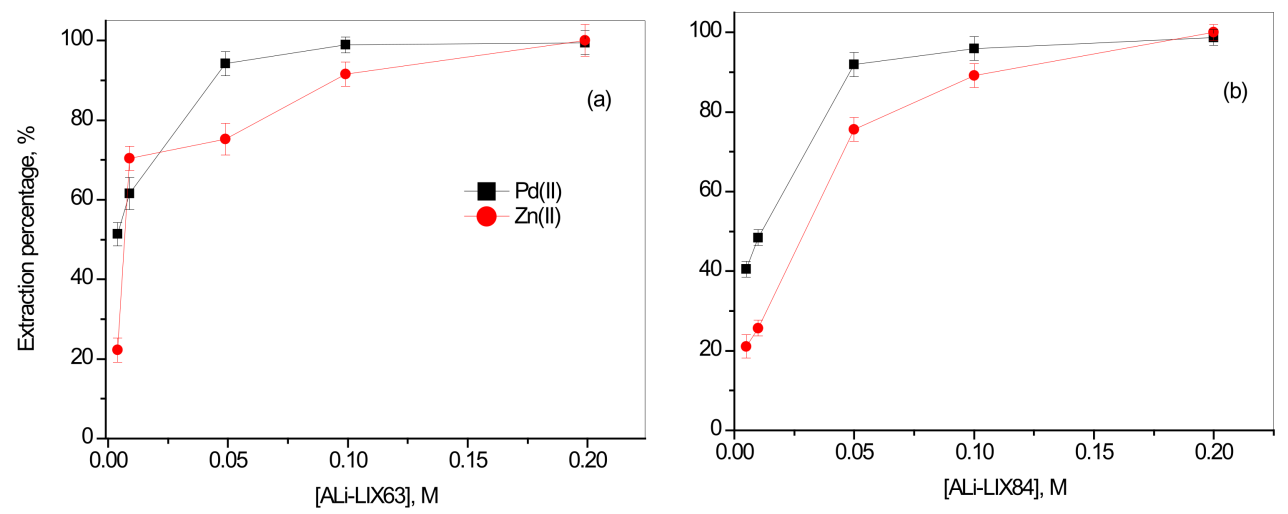

Figure 7. Effect of (a) ALi-LIX63 and (b) ALi-LIX84 concentration on extraction of Pd(II) and Zn(II). Conditions: [extractant] $=0.005-0.2 \mathrm{M}$, diluent: kerosene; modifier: decanol $10 \% v / v . \mathrm{A} / \mathrm{O}=1$, real leaching solution of $5 \mathrm{M} \mathrm{H}_{2} \mathrm{SO}_{4}$ and $1.5 \% \mathrm{NaClO} ;[\mathrm{Pd}(\mathrm{II})]=1926 \mathrm{mg} / \mathrm{L}$ and $[\mathrm{Zn}(\mathrm{II})]=74 \mathrm{mg} / \mathrm{L}$.

The co-extraction of $\mathrm{Zn}(\mathrm{II})$ in these experiments was attributed to the use of $\mathrm{NaClO}$ as an oxidizing agent during sulfuric acid leaching of the cemented Pd. The standard reduction potentials of $\mathrm{Pd}(\mathrm{II})$ and hypochlorite ions at $25^{\circ} \mathrm{C}$ are represented as follows [41]:

$$
\begin{gathered}
\mathrm{ClO}^{-}+2 \mathrm{H}^{+}+2 \mathrm{e}=\mathrm{Cl}^{-}+\mathrm{H}_{2} \mathrm{O}, \mathrm{E}^{\mathrm{o}}=1.715 \mathrm{~V} \\
\mathrm{Pd}^{2+}+2 \mathrm{e}=\mathrm{Pd}, \mathrm{E}^{\mathrm{o}}=0.987 \mathrm{~V}
\end{gathered}
$$

Equations (10) and (11) indicate that the hypochlorite ions can be reduced to chloride ions during the leaching of the cemented $\mathrm{Pd}$ with the mixture of $\mathrm{H}_{2} \mathrm{SO}_{4}$ and $\mathrm{NaClO}$ at $25^{\circ} \mathrm{C}$. According to the HSAB principle, $\mathrm{Pd}(\mathrm{II})$ is a soft acid, while $\mathrm{Zn}$ (II) is classified as borderline. Since chloride ions are a hard base, $\mathrm{Zn}$ (II) has a stronger tendency to form chloro complexes than $\mathrm{Pd}(\mathrm{II})$. Compared to pure sulfuric acid solution, the extraction of $\mathrm{Zn}$ (II) is enhanced in the real leaching solution owing to the formation of $\mathrm{Zn}$ (II)-chloro complexes [34,42]. According to our results on the leaching of Pd and Zn metal, Pd metal would not be dissolved in the sulfuric acid solution when hydrogen peroxide is employed as an oxidizing agent [2], and thus the use of $\mathrm{NaClO}$ is necessary.

The extraction data with the real leaching solution indicate that removal of chloride ions is necessary to apply the separation conditions obtained from pure synthetic sulfuric acid solutions.

\section{Conclusions}

The separation of $\mathrm{Pd}$ (II) and $\mathrm{Zn}$ (II) from synthetic sulfuric acid leaching solutions of cemented Pd from spent electroplating solutions was investigated by solvent extraction with synthesized ILs. Among the ILs employed in this work, ALi-LIX63 and ALi-LIX84 completely separated $\mathrm{Pd}$ (II) over $\mathrm{Zn}(\mathrm{II})$ in the $\mathrm{H}_{2} \mathrm{SO}_{4}$ concentration range from 0.5 to $9 \mathrm{M}$, whereas the selective extraction of Pd(II) by ILs such as ALi-CY301, ALi-SCN, ALi-I and $\mathrm{ALi}-\mathrm{Br}$ depended on $\mathrm{H}_{2} \mathrm{SO}_{4}$ concentrations. Namely, selective extraction of $\mathrm{Pd}(\mathrm{II})$ by $\mathrm{ALi}-\mathrm{I}$ and $\mathrm{ALi}-\mathrm{Br}$ was possible when $\mathrm{H}_{2} \mathrm{SO}_{4}$ concentration was low $(0.5-3 \mathrm{M})$, while ALi-CY301 and ALi-SCN were effective in selective extraction of $\mathrm{Pd}(\mathrm{II})$ from concentrated $\mathrm{H}_{2} \mathrm{SO}_{4}$ concentrations (7-9 M). It was found that control of ALi-CY301 concentration was very important to separate $\mathrm{Pd}(\mathrm{II})$ over $\mathrm{Zn}(\mathrm{II})$. Two kinds of synthesized ILs with organic (ALi-CY301, ALi-CY272, ALi-LIX63, ALi-LIX84) and inorganic anions (ALi-I, ALi-Br, ALi-SCN) were selective for Pd(II) extraction. Pd(II) from the loaded phase of ALi-LIX63 and ALi-LIX84 was completely stripped by the mixture of $\mathrm{HCl}$ and thiourea. Aqua regia solutions were effective for stripping of $\mathrm{Pd}(\mathrm{II})$ from the loaded ALi-CY301. Stripping of $\mathrm{Pd}$ (II) from loaded ALi-I and ALi-Br was possible by the $0.5 \mathrm{M} \mathrm{NH}_{3}$ solution, while $98.4 \%$ of $\mathrm{Pd}(\mathrm{II})$ was stripped from the loaded ALi-SCN by using a mixture of $\mathrm{NH}_{4} \mathrm{Cl}$ and $\mathrm{NH}_{3}$ solutions. 
Application of the extraction conditions to the real $5 \mathrm{M}$ sulfuric acid leaching solution of cemented Pd indicated that it was difficult to separate $\mathrm{Pd}(\mathrm{II})$ and $\mathrm{Zn}$ (II) by extraction with ALi-LIX63 and ALi-LIX84. The use of $\mathrm{NaClO}$ as an oxidizing agent during the sulfuric acid leaching of real cemented Pd resulted in an enhancement of $\mathrm{Zn}(\mathrm{II})$ extraction by ALi-LIX63 and ALi-LIX84. Our results indicate that it is necessary to remove chloride ions from the sulfuric acid leaching solution to apply the separation conditions obtained from synthetic sulfuric acid solutions.

Author Contributions: Methodology and editing, M.-S.L.; data support, S.-J.S.; writing—original draft preparation, V.-N.N. All authors have read and agreed to the published version of the manuscript.

Funding: This work was supported by the Technology Innovation Program (Development of Material Component Technology) (Project number: 20013071) funded by the Ministry of Trade, Industry and Energy (MOTIE, Korea).

Institutional Review Board Statement: Not applicable.

Informed Consent Statement: Not applicable.

Data Availability Statement: Data is contained within this article.

Acknowledgments: We gratefully thank the Gwangju branch of the Korea Basic Science (KBSI) for ICP data.

Conflicts of Interest: The authors declare no conflict of interest.

\section{References}

1. Antler, M. The Application of Palladium in Electronic Connectors Continuing Studies result in Growing use. Platin. Met. Rev. 1982, 26, 106-117.

2. Song, S.J.; Nguyen, V.N.H.; Lee, M.S. Leaching of a Mixture of Palladium and Zinc Metal Using Hydrochloric and Sulfuric Acid Solutions. Korean J. Met. Mater. 2021, 59, 469-475. [CrossRef]

3. Nguyen, T.H.; Sonu, C.H.; Lee, M.S. Separation of Pt(IV), Pd(II), Rh(III) and Ir(IV) from concentrated hydrochloric acid solutions by solvent extraction. Hydrometallurgy 2016, 164, 71-77. [CrossRef]

4. Truong, H.T.; Lee, M.S. Separation of Pd(II) and Pt(IV) from hydrochloric acid solutions by solvent extraction with Cyanex 301 and LIX 63. Miner. Eng. 2018, 115, 13-20. [CrossRef]

5. Gupta, B.; Singh, I. Extraction and separation of platinum, palladium and rhodium using Cyanex 923 and their recovery from real samples. Hydrometallurgy 2013, 134-135, 11-18. [CrossRef]

6. Reddy, B.R.; Raju, B.; Lee, J.-Y.; Park, H.K. Process for the separation and recovery of palladium and platinum from spent automobile catalyst leach liquor using LIX 84I and Alamine 336. J. Hazard. Mater. 2010, 180, 253-258. [CrossRef] [PubMed]

7. Rovira, M.; Cortina, J.L.; Amaldos, J.; Sastre, A.M. Recovery and separation of platinum group metals using impregnated resins containing alamine 336. Solvent Extr. Ion Exch. 1998, 16, 1279-1302. [CrossRef]

8. Schreier, G.; Edtmaier, C. Separation of Ir, Pd and Rh from secondary Pt scrap by precipitation and calcination. Hydrometallurgy 2003, 68, 69-75. [CrossRef]

9. Nguyen, V.T.; Riaño, S.; Binnemans, K. Separation of precious metals by split-anion extraction using water-saturated ionic liquids. Green Chem. 2020, 22, 8375-8388. [CrossRef]

10. Cieszyńska, A.; Wisniewski, M. Selective extraction of palladium(II) from hydrochloric acid solutions with phosphonium extractants. Sep. Purif. Technol. 2011, 80, 385-389. [CrossRef]

11. Crundwell, F.K.; Moats, M.; Ramachandran, V.; Robinson, T.G.; Davenport, W.G. Extractive Metallurgy of Nickel, Cobalt and Platinum Group Metals; Elsevier: Oxford, UK, 2011.

12. Rane, M.; Venugopal, V. Study on the extraction of palladium(II) and platinum(IV) using LIX 84I. Hydrometallurgy 2006, 84, 54-59. [CrossRef]

13. Pan, L.; Zhang, Z.-D. Solvent extraction and separation of palladium(II) and platinum(IV) from hydrochloric acid medium with dibutyl sulfoxide. Miner. Eng. 2009, 22, 1271-1276. [CrossRef]

14. Paiva, A.P.; Carvalho, G.; Costa, M.C.; Da Costa, A.M.R.; Nogueira, C. Recovery of Platinum and Palladium from Chloride Solutions by a Thiodiglycolamide Derivative. Solvent Extr. Ion Exch. 2013, 32, 78-94. [CrossRef]

15. Swain, B.; Jeong, J.; Kim, S.-K.; Lee, J.-C. Separation of platinum and palladium from chloride solution by solvent extraction using Alamine 300. Hydrometallurgy 2010, 104, 1-7. [CrossRef]

16. Cox, M. Solvent extraction in hydrometallurgy. In Solvent Extraction Principles and Practice, 2nd ed.; Rydberg, J., Cox, M., Musikas, C., Choppin, G.R., Eds.; Marcel Dekker Inc.: New York, NY, USA, 2004; pp. 455-505.

17. Onghena, B.; Valgaeren, S.; Hoogerstraete, T.V.; Binnemans, K. Cobalt(ii)/nickel(ii) separation from sulfate media by solvent extraction with an undiluted quaternary phosphonium ionic liquid. RSC Adv. 2017, 7, 35992-35999. [CrossRef] 
18. Nguyen, T.H.; Sonu, C.H.; Lee, M.S. Separation of platinum(IV) and palladium(II) from concentrated hydrochloric acid solutions by mixtures of amines with neutral extractants. J. Ind. Eng. Chem. 2015, 32, 238-245. [CrossRef]

19. Nayl, A. Extraction and separation of $\mathrm{Co}(\mathrm{II})$ and Ni(II) from acidic sulfate solutions using Aliquat 336. J. Hazard. Mater. 2010, 173, 223-230. [CrossRef]

20. Tran, T.T.; Azra, N.; Iqbal, M.; Lee, M.S. Synthesis of succinimide based ionic liquids and comparison of extraction behavior of $\mathrm{Co}(\mathrm{II})$ and $\mathrm{Ni}$ (II) with bi-functional ionic liquids synthesized by Aliquat336 and organophosphorus acids. Sep. Purif. Technol. 2020, 238, 116496. [CrossRef]

21. Nguyen, V.N.H.; Lee, M.S. Separation of $\mathrm{Co}(\mathrm{II}), \mathrm{Ni}(\mathrm{II}), \mathrm{Mn}(\mathrm{II})$ and $\mathrm{Li}(\mathrm{I})$ from synthetic sulfuric acid leaching solution of spent lithium ion batteries by solvent extraction. J. Chem. Technol. Biotechnol. 2021, 96, 1205-1217. [CrossRef]

22. Preston, J.S. Solvent Extraction of Cobalt(II) and Nickel(II) by a Quaternary Ammonium Thiocyanate. Sep. Sci. Technol. 1982, 17, 1697-1718. [CrossRef]

23. Colombo, C.; Oates, C.; Monhemius, A.; Plant, J. Complexation of platinum, palladium and rhodium with inorganic ligands in the environment. Geochem. Explor. Environ. Anal. 2008, 8, 91-101. [CrossRef]

24. Shi, T.; Elding, L.I.; Mel'nikov, M.Y.; Feldman, V.I.; Kristjánsdóttir, Á.G.; Matsson, O.; Mikkelsen, K.V.; Senning, A. Equilibria, Kinetics and Mechanism for Complex Formation between Hydrogen Sulfate/Sulfate and Palladium(II). Hydrolysis of Tetraaquapalladium(II). Acta Chem. Scand. 1998, 52, 897-902. [CrossRef]

25. Katsuta, S.; Yoshimoto, Y.; Okai, M.; Takeda, Y.; Bessho, K. Selective Extraction of Palladium and Platinum from Hydrochloric Acid Solutions by Trioctylammonium-Based Mixed Ionic Liquids. Ind. Eng. Chem. Res. 2011, 50, 12735-12740. [CrossRef]

26. Yang, J.; Kubota, F.; Baba, Y.; Kamiya, N.; Goto, M. One Step Effective Separation of Platinum and Palladium in an Acidic Chloride Solution by Using Undiluted Ionic Liquids. Solvent Extr. Res. Dev. Jpn. 2014, 21, 129-135. [CrossRef]

27. Sasaki, K.; Takao, K.; Suzuki, T.; Mori, T.; Arai, T.; Ikeda, Y. Extraction of Pd(ii), Rh(iii) and Ru(iii) from HNO3 aqueous solution to betainium bis(trifluoromethanesulfonyl)imide ionic liquid. Dalton Trans. 2014, 43, 5648-5651. [CrossRef]

28. Fortuny, A.; Coll, M.; Sastre, A.M. Use of methyltrioctyl/decylammonium bis 2,4,4-(trimethylpentyl)phosphinate ionic liquid (ALiCY IL) on the boron extraction in chloride media. Sep. Purif. Technol. 2012, 97, 137-141. [CrossRef]

29. Nguyen, T.T.N.; Nguyen, V.N.H.; Liu, Y.; Lee, M.S. Analysis of the interaction in the mixture of organophosphorus acids and Aliquat 336 through the measurement of dielectric constant and viscosity. J. Mol. Liq. 2020, 315, 113738. [CrossRef]

30. Le Roux, C.J.; Gans, P.R.; Kriek, J. Complexation of palladium(II) with thiocyanate-A spectrophotometric investigation. J. Coord. Chem. 2014, 67, 1520-1529. [CrossRef]

31. Elding, L. Palladium(II) halide complexes. I. Stabilities and spectra of palladium(II) chloro and bromo aqua complexes. Inorganica Chim. Acta 1972, 6, 647-651. [CrossRef]

32. Elding, L. Stabilities of platinum(II) chloro and bromo complexes and kinetics for anation of the tetraaquaplatinum(II) ion by halides and thiocyanate. Inorganica Chim. Acta 1978, 28, 255-262. [CrossRef]

33. Elding, L.I.; Olsson, L.-F. Stabilities, solubility, and kinetics and mechanism for formation and hydrolysis of some palladium(II)and platinum(II) iodo complexes in aqueous solution. Inorganica Chim. Acta 1986, 117, 9-16. [CrossRef]

34. Burgess, J.R.; Prince, H. Zinc: Inorganic and Coordination Chemistry. Based in part on the article Zinc: Inorganic and Coordination Chemistry by Reg H. Prince which appeared in the Encyclopedia of Inorganic Chemistry, First Edition. In Encyclopedia of Inorganic and Bioinorganic Chemistry, 1st ed.; John Wiley and Sons, Ltd.: Hoboken, NJ, USA, 2006; pp. 1-22. [CrossRef]

35. Tait, B.K. The extraction of some base metal ions by cyanex 301 cyanex 302 and their binary extractant mixtures with aliquat 336 . Solvent Extr. Ion Exch. 1992, 10, 799-809. [CrossRef]

36. Dupont, D.; Depuydt, D.; Binnemans, K. Overview of the Effect of Salts on Biphasic Ionic Liquid/Water Solvent Extraction Systems: Anion Exchange, Mutual Solubility, and Thermomorphic Properties. J. Phys. Chem. B 2015, 119, 6747-6757. [CrossRef]

37. Matveichuk, Y.V.; Rakhman'ko, E.M.; Yasinetskii, V.V. Thiocyanate complexes of d metals: Study of aqueous solutions by UV, visible, and IR spectrometry. Russ. J. Inorg. Chem. 2015, 60, 100-104. [CrossRef]

38. Hiromitsu, M.; Tatsuya, S. Stability and Extractability of Zinc (II) Thiocyanate complexes in several solvent extraction systems. Bull. Chem. Soc. Jpn. 1971, 44, 3347-3352.

39. Nguyen, V.N.H.; Lee, M.S. Solvent extraction of Hydrochloric Acid Using Commercial Extractants and Synthesized Ionic Liquids. J. Korean Inst. Resour. Recycl. 2020, 29, 79-87.

40. Landini, D.; Maia, A.; Rampoldi, A. Stability of quaternary onium salts under phase-transfer conditions in the presence of aqueous alkaline solutions. J. Org. Chem. 1986, 51, 3187-3191. [CrossRef]

41. Pourbaix, M. Atlas of Electrochemical Equilibria in Aqueous Solutions; Pergamon Press: London, UK, 1966 ; pp. $359-591$.

42. Sato, T.; Nakamura, T.; Fujimatsu, T. Extraction of bivalent Manganese, Cobalt, Copper, Zinc, and Cadmium from hydrochloric acid solutions by long-chain alkyl quaternary ammonium chloride in various organic solvents. Bull. Chem. Soc. Jpn. 1981, 54, 2656-2661. [CrossRef] 